\title{
Influence of infrastructure on water quality and greenhouse gas dynamics in urban streams
}

\author{
Rose M. Smith ${ }^{1,2}$, Sujay S. Kaushal ${ }^{2}$, Jake J. Beaulieu ${ }^{3}$, Michael J. Pennino ${ }^{4,5}$, and Claire Welty ${ }^{5}$ \\ ${ }^{1}$ Department of Biology, University of Utah, Salt Lake City, UT 84112, USA \\ ${ }^{2}$ Department of Geology, Earth System Science Interdisciplinary Center, University of Maryland, \\ College Park, MD 20742, USA \\ ${ }^{3}$ US Environmental Protection Agency, Office of Research and Development, National Risk \\ Management Research Laboratory, Cincinnati, OH 45220, USA \\ ${ }^{4}$ US Environmental Protection Agency National Health and Environmental Effects Research Lab, \\ Corvallis, OR 97333, USA \\ ${ }^{5}$ Department of Chemical, Biochemical, and Environmental Engineering, Center for Urban \\ Environmental Research and Education, University of Maryland Baltimore County, Baltimore, \\ MD 21250, USA
}

Correspondence to: Rose M. Smith (smithrose24@gmail.com)

Received: 8 September 2016 - Discussion started: 15 September 2016

Revised: 11 March 2017 - Accepted: 18 April 2017 - Published: 13 June 2017

\begin{abstract}
Streams and rivers are significant sources of nitrous oxide $\left(\mathrm{N}_{2} \mathrm{O}\right)$, carbon dioxide $\left(\mathrm{CO}_{2}\right)$, and methane $\left(\mathrm{CH}_{4}\right)$ globally, and watershed management can alter greenhouse gas (GHG) emissions from streams. We hypothesized that urban infrastructure significantly alters downstream water quality and contributes to variability in GHG saturation and emissions. We measured gas saturation and estimated emission rates in headwaters of two urban stream networks (Red Run and Dead Run) of the Baltimore Ecosystem Study Long-Term Ecological Research project. We identified four combinations of stormwater and sanitary infrastructure present in these watersheds, including: (1) stream burial, (2) inline stormwater wetlands, (3) riparian/floodplain preservation, and (4) septic systems. We selected two firstorder catchments in each of these categories and measured GHG concentrations, emissions, and dissolved inorganic and organic carbon (DIC and DOC) and nutrient concentrations biweekly for 1 year. From a water quality perspective, the DOC : $\mathrm{NO}_{3}^{-}$ratio of streamwater was significantly different across infrastructure categories. Multiple linear regressions including DOC: $\mathrm{NO}_{3}^{-}$and other variables (dissolved oxygen, DO; total dissolved nitrogen, TDN; and temperature) explained much of the statistical variation in nitrous oxide $\left(\mathrm{N}_{2} \mathrm{O}, r^{2}=0.78\right)$, carbon dioxide $\left(\mathrm{CO}_{2}, r^{2}=0.78\right)$,
\end{abstract}

and methane $\left(\mathrm{CH}_{4}, r^{2}=0.50\right)$ saturation in stream water. We measured $\mathrm{N}_{2} \mathrm{O}$ saturation ratios, which were among the highest reported in the literature for streams, ranging from 1.1 to 47 across all sites and dates. $\mathrm{N}_{2} \mathrm{O}$ saturation ratios were highest in streams draining watersheds with septic systems and strongly correlated with TDN. The $\mathrm{CO}_{2}$ saturation ratio was highly correlated with the $\mathrm{N}_{2} \mathrm{O}$ saturation ratio across all sites and dates, and the $\mathrm{CO}_{2}$ saturation ratio ranged from 1.1 to $73 . \mathrm{CH}_{4}$ was always supersaturated, with saturation ratios ranging from 3.0 to 2157 . Longitudinal surveys extending form headwaters to third-order outlets of Red Run and Dead Run took place in spring and fall. Linear regressions of these data yielded significant negative relationships between each gas with increasing watershed size as well as consistent relationships between solutes (TDN or DOC, and DOC : TDN ratio) and gas saturation. Despite a decline in gas saturation between the headwaters and stream outlet, streams remained saturated with GHGs throughout the drainage network, suggesting that urban streams are continuous sources of $\mathrm{CO}_{2}$, $\mathrm{CH}_{4}$, and $\mathrm{N}_{2} \mathrm{O}$. Our results suggest that infrastructure decisions can have significant effects on downstream water quality and greenhouse gases, and watershed management strategies may need to consider coupled impacts on urban water and air quality. 


\section{Introduction}

Streams and rivers are dynamic networks that emit globally significant quantities of carbon dioxide $\left(\mathrm{CO}_{2}\right)$, methane $\left(\mathrm{CH}_{4}\right)$, and nitrous oxide $\left(\mathrm{N}_{2} \mathrm{O}\right)$ to the atmosphere. $\mathrm{CO}_{2}$ emissions via flowing waters are equivalent to half of the annual terrestrial carbon sink $\left(1.2 \mathrm{Pg} \mathrm{CO}_{2}-\mathrm{C} \mathrm{yr}^{-1}\right.$, Cole et al., 2007; Battin et al., 2008). Stanley et al. (2016) recently demonstrated that flowing waters are significant $\mathrm{CH}_{4}$ sources as well, emitting approximately $28 \mathrm{Tg} \mathrm{yr}^{-1}$, which is equivalent to between 10 and $35 \%$ of emissions from wetlands globally (Bridgham et al., 2013). Approximately $10 \%$ of global anthropogenic $\mathrm{N}_{2} \mathrm{O}$ emissions are emitted from river networks due to nitrogen contamination of surface and groundwater (UNEP, 2013; Ciais et al., 2013). There is evidence that these $\mathrm{N}_{2} \mathrm{O}$ estimates, based on IPCC guidelines, might be too low, given growing evidence of high denitrification rates in small streams with high $\mathrm{NO}_{3}^{-}$loads (Beaulieu et al., 2011).

While much of the research on greenhouse gas (GHG) emissions from streams has taken place in agricultural watersheds, urban-impacted river networks receive similar $\mathrm{N}$ loads and have also shown elevated GHG concentrations and emissions (e.g., Daniel et al., 2001; Beaulieu et al., 2010, 2011; Kaushal et al., 2014a; Gallo et al., 2014). As urban land cover and populations continue to expand, it is critical to understand the impacts on downstream waters, including $\mathrm{C}$ and $\mathrm{N}$ loading and $\mathrm{GHG}$ emissions. While $\mathrm{N}_{2} \mathrm{O}$ emissions from both urban and agricultural sources are taken into account in models based on estimated watershed dissolved inorganic nitrogen loading (Nevison et al., 2000; Seitzinger et al., 2000), measurements validating these estimates or estimates of $\mathrm{CO}_{2}$ and $\mathrm{CH}_{4}$ in urban watersheds are rare. Quantifying the variability, drivers, and sources of GHG emissions from streams will illuminate the biogeochemical processes and potential role of urban infrastructure on nutrient cycling, water quality, and GHG budgets.

\subsection{Role of sanitary infrastructure}

The form and age of stormwater and sanitary infrastructure within a watershed can influence stream water GHG emissions in several ways. GHGs may enter urban streams directly through buried stormwater and sanitary infrastructure or form increased production within streams in response to nutrient loading and/or geomorphic changes. We investigated the role of infrastructure on GHG emissions from streams in order to evaluate these potential drivers of heterogeneity within urban watersheds. Sanitary infrastructure encompasses a wide array of systems to manage human waste. In developed countries, sanitary infrastructure includes a combination of septic systems, sanitary sewers, and sometimes combined stormwater and sanitary sewers. Storm and sanitary sewer lines are present in areas with medium-to-highdensity development. The sanitary sewer or combined sewer network delivers waste to centralized wastewater treatment plants (WWTPs), which treat influent and release effluent into larger rivers or coastal zones. Sanitary, storm, and combined sewers tend to follow stream valleys (i.e., low points in the landscape), are often made of erodible materials such as terra cotta or concrete, and tend to crack or develop leaks. Leaks in sanitary sewer infrastructure can lead to chronic nutrient loading throughout stream networks (Divers et al., 2013, Kaushal et al., 2011, 2015; Pennino et al., 2016). Septic systems, primarily used in low-density residential areas, are designed to settle out waste solids and leach $\mathrm{N}$-rich liquid waste into subsurface soils and groundwater. Sanitary sewer infrastructure may influence GHG abundance and emission from streams directly via diffusion of gases out of gravity sewer lines (Short et al., 2014) or indirectly by microbial processing along surface and subsurface flow paths (Yu et al., 2013; Beaulieu et al., 2011). While the present study focuses mainly on first- to third-order streams influenced by sanitary sewer lines or septic systems, it is also worth mentioning that WWTPs are known to be a source of $\mathrm{CH}_{4}$ and $\mathrm{N}_{2} \mathrm{O}$ in urban areas and contribute point-source GHG loading to larger rivers and coastal areas (Beaulieu et al., 2010; Strokal and Kroeze, 2014; Alshboul et al., 2016).

Sewage leaks are likely the primary source of $\mathrm{N}_{2} \mathrm{O}$ emissions from small urban streams (Short et al., 2014). Several studies have documented that wastewater leakage from municipal sewers often accounts for more than $50 \%$ of dissolved N in urban streams (Kaushal et al., 2011; Pennino et al., 2016; Divers et al., 2013). While sanitary sewer lines are known to leak dissolved $\mathrm{N}, \mathrm{N}_{2} \mathrm{O}$ losses are not accounted for in greenhouse gas budgets of the large WWTPs that these pipes feed into. Short et al. (2014) measured intake lines from three municipal WWTPs and estimated that $\mathrm{N}_{2} \mathrm{O}$ emissions from sewer lines alone are on the same order of magnitude $\left(1.7 \mathrm{~g} \mathrm{~N}_{2} \mathrm{O}\right.$ person $\left.\mathrm{yr}^{-1}\right)$ as current IPCC estimates for per capita emissions from secondary WWTPs. Their study demonstrates the importance of constraining biogenic gas emissions from streams, which flow alongside and may receive gaseous inputs from aging sanitary sewer lines.

\subsection{Role of stormwater infrastructure}

Stormwater infrastructure varies widely across and within cities. From stream burial in pipes to infiltration-based green infrastructure (GI) designs, stormwater management (SWM) designs have evolved over time (Collins et al., 2010; Kaushal et al., 2014b). In Baltimore, where this study took place, stormwater management installed prior to the 1970s consisted of concrete-lined channels and buried streams (Baltimore County Department of Planning, 2010). Areas developed during the 1990s and 2000s are characterized by a more GI-based design approach, including but not limited to upland detention ponds, infiltration basins, wetlands and bioswales. Stream restoration projects and riparian zone protections have also been established, restricting development 
within $100 \mathrm{~m}$ of the stream corridor for new developments (Baltimore Department of planning, 2010).

The form of stormwater infrastructure - whether stream burial, infiltration wetland, or restored riparian zone - may contribute to GHG saturation of groundwater and streams. Stormwater control wetlands and riparian/floodplain preservation may increase or decrease $\mathrm{CH}_{4}$ and $\mathrm{N}_{2} \mathrm{O}$ emissions from streams, depending upon how watershed $\mathrm{C}$ and $\mathrm{N}$ inputs are routed along hydro-biogeochemical flow paths. For instance, if these forms of GI are successful at removing excess $\mathrm{N}$ inputs to streams, GI may reduce $\mathrm{N}_{2} \mathrm{O}$ emissions from flowing waters. Alternatively, GI may increase both $\mathrm{N}_{2} \mathrm{O}$ and $\mathrm{CH}_{4}$ inputs to streams and thus emissions by facilitating anaerobic microbial metabolism (Søvik et al., 2006; VanderZaag et al., 2010). The form of GI (i.e., stormwater control wetland vs. riparian/floodplain preservation) may also influence GHGs due to (1) differences in water residence time and oxygen depletion in wetland vs. floodplain soils and (2) differences in watershed-scale $\mathrm{N}$ removal capacity of the two different approaches.

\subsection{Variables controlling GHG production in urban watersheds}

Reach-scale studies in streams across biomes have demonstrated that GHG production and emission is sensitive to changes in nutrient stoichiometry, organic matter quality, redox state, and temperature (e.g., Bernot et al., 2010; Kaushal et al., 2014a; Beaulieu et al., 2009; Dinsmore et al., 2009; Baulch et al., 2011; Harrison and Matson, 2003). Several studies have shown that infrastructure can influence solute loading and stoichiometry of streams, which could in turn increase GHG production. For instance, Newcomer et al. (2012) measured higher rates of $\mathrm{N}$ uptake and denitrification potential in streams with restored riparian zones compared with degraded, incised urban streams. In-stream $\mathrm{N}$ uptake is also consistently higher in daylighted streams compared with streams buried in pipes (Pennino et al., 2014; Beaulieu et al., 2015). Upland or inline stormwater wetlands and retention ponds provide additional locations for focused $\mathrm{N}$ removal in urban watersheds (Newcomer Johnson et al., 2014; Bettez and Groffman, 2012). Sanitary infrastructure (i.e., leaky sewer lines and septic systems) can also be a source of $\mathrm{N}$ via leaching into groundwater (Shields et al., 2008; Kaushal et al., 2015; Pennino et al., 2016).

In previous studies, carbon quantity and/or organic matter quality was correlated with $\mathrm{N}$ uptake or removal in urban streams and wetlands (Newcomer et al., 2012; Pennino et al., 2014; Beaulieu et al., 2015; Bettez and Groffman, 2012; Kaushal et al., 2014c). Inverse relationships between dissolved organic carbon (DOC) and nitrate $\left(\mathrm{NO}_{3}^{-}\right)$ concentrations have been found to persist across a wide variety of ecosystems ranging from soils to streams to oceans (e.g., Aitkenhead-Peterson and McDowell, 2000; Dodds et al., 2004; Kaushal and Lewis, 2005; Taylor and Townsend,
2010). Recently, inverse relationships between DOC and $\mathrm{NO}_{3}^{-}$have also been reported for urban environments ranging from groundwater to streams to river networks (Mayer et al., 2010; Kaushal and Belt, 2012; Kaushal et al., 2014c). A suite of competing biotic processes may control this relationship, by either (1) assimilating or reducing $\mathrm{NO}_{3}^{-}$in the presence of bioavailable DOC or (2) by producing $\mathrm{NO}_{3}^{-}$ regardless of DOC status (Hedin et al., 1998; Dodds et al., 2004; Kaushal and Lewis, 2005; Taylor and Townsend, 2010). The former category includes heterotrophic denitrification, which oxidizes organic carbon to $\mathrm{CO}_{2}$ and reduces $\mathrm{NO}_{3}^{-}$to $\mathrm{N}_{2} \mathrm{O}+\mathrm{N}_{2}$ (Knowles, 1982) as well as assimilation of inorganic N (Wymore et al., 2015; Caraco et al., 1998; Kaushal and Lewis, 2005). In the second category, nitrification chemoautotrophically produces $\mathrm{NO}_{3}^{-}$by oxidizing $\mathrm{NH}_{4}^{+}$and consuming $\mathrm{CO}_{2}$. Nitrification also yields $\mathrm{N}_{2} \mathrm{O}$ as an intermediate product and has been shown to dominate $\mathrm{N}$ cycling processes in low-DOC environments (Schlesinger, 1997; Taylor and Townsend, 2010; Helton et al., 2015).

In urban watersheds, denitrification is often limited by DOC due to increased $\mathrm{N}$ loading and/or decreased connectivity with carbon-rich soils in the riparian zone (Mayer et al., 2010; Newcomer et al., 2012). The C: $\mathrm{N}$ stoichiometry is likely to be affected by stormwater and sanitary sewer infrastructure designs as well (Søvik et al., 2006; Collins et al., 2010; Kaushal et al., 2011). Stormwater wetlands may promote anoxic conditions and increase the $\mathrm{C}: \mathrm{N}$ ratio of stream water by increasing flow through carbon-rich soils (e.g., Søvik et al., 2006; Newcomer et al., 2012). Stream burial can reduce $\mathrm{C}: \mathrm{N}$ ratios, if streams are buried in storm drains (Pennino et al., 2016; Beaulieu et al., 2014). Leaky sanitary infrastructure may additionally reduce the $\mathrm{C}: \mathrm{N}$ ratio and/or alter the form of carbon in streams (Newcomer et al., 2012).

\subsection{Study goals}

The goal of the present study was to identify patterns and drivers related to GHG dynamics in urban headwater streams draining different forms of infrastructure (stream burial, septic systems, inline SWM wetlands, and riparian/floodplain preservation). Although less considered compared with nutrient loading, increased GHG emissions may be an unintended consequence of urban water quality impairments and biogeochemical processes occurring within and downstream of urban infrastructure. A growing body of work has shown that nutrient and carbon loads to streams are related not only to land cover metrics (\% impervious surface, urban density, etc.) but also to urban infrastructure (Shields et al., 2008; Kaushal et al., 2014b). Connectivity between runoff-generating water sources (groundwater, overland flow, and shallow subsurface flow) and urban infrastructure (sanitary sewer lines, storm sewers, drinking water pipes, constructed wetlands, etc.) is likely to influence nutrient export and the biogeochemical function of waterways. An improved 

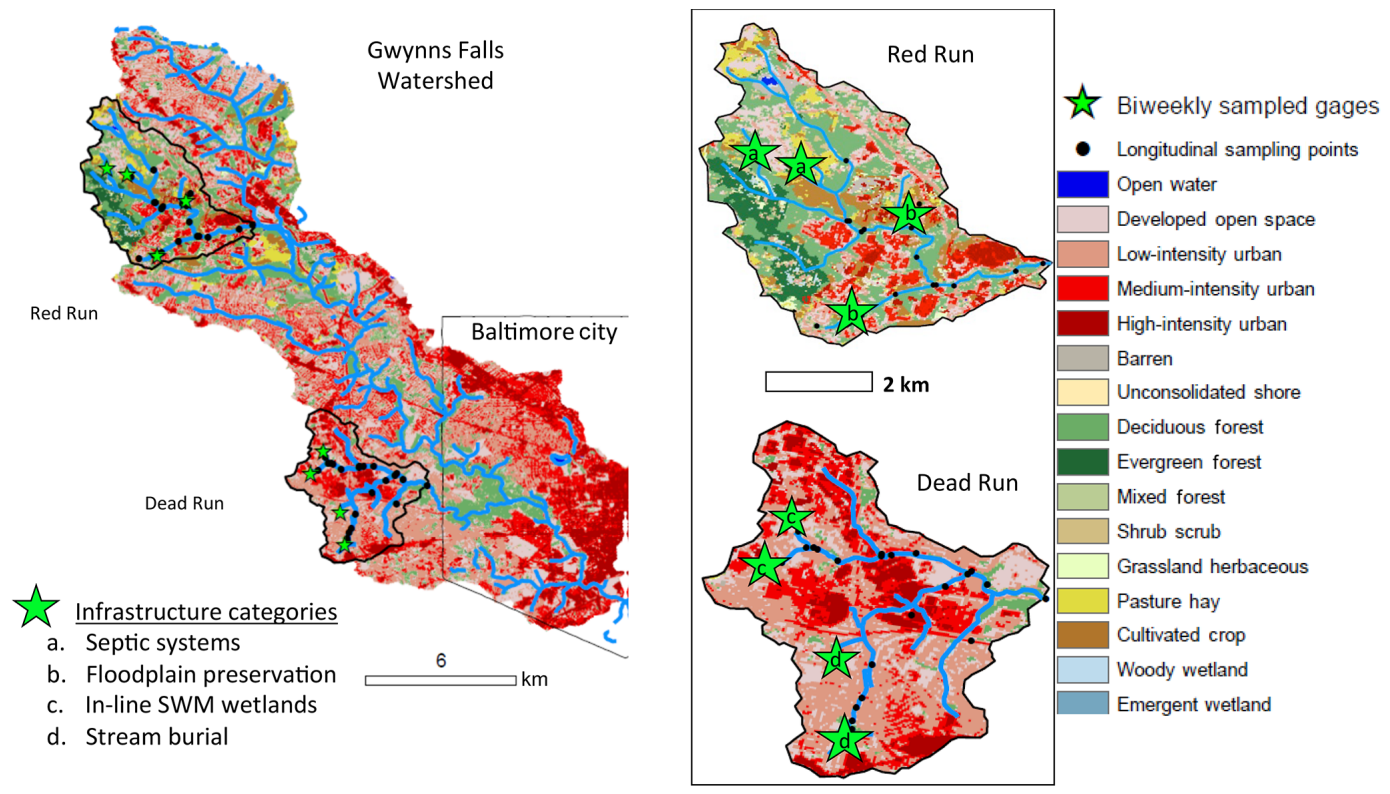

Figure 1. Site map of headwater stream sites within Red Run and Dead Run watersheds. Green stars signify biweekly sampling sites, and black dots signify longitudinal sampling points sampled seasonally. Land cover categories are colored based on the National Land Cover Database, with dark red areas signifying dense urban land cover, light red signifying medium urban land cover, and green colors signifying forested or undeveloped areas. Close-up views of Dead Run and Red Run on the right represent the study watersheds.

understanding of the relationship between infrastructure type and biogeochemical functions is critical for minimizing unintended consequences of water quality management, especially as growing urban populations place greater burden on watershed infrastructure (Doyle et al., 2008; Foley et al., 2005; Strokal and Kroeze, 2014).

\subsection{Sampling methods}

\subsubsection{Study sites}

This study took place in collaboration with the Baltimore Ecosystem Study Long-Term Ecological Research project (www.beslter.org). We identified four categories based on distinct combinations of stormwater and sanitary infrastructure dominating the greater Baltimore region, based on maps of stormwater control structures, housing age, and intensive field surveys. We then selected eight first-order streams paired across the four categories. First-order stream sites were spread equally across two sub-watersheds of Gwynns Falls: Dead Run and Read Run (Fig. 1). We have abbreviated the categories based on the dominant infrastructure feature as follows: (1) stream burial, (2) inline stormwater management wetlands, (3) riparian/floodplain preservation, and (4) septic systems (Table 1).

Sites in the "stream burial" category (DRAL and DIRS) drain watersheds with streams contained in storm sewers. Sanitary infrastructure in these watersheds is composed of aged sanitary sewer lines, installed prior to 1970 (Baltimore County Department of Planning, 2010). Streams in the "inline stormwater management" category (DRKV and DRGG) originate in stormwater ponds or wetlands and also flow adjacent to aging sanitary sewer lines. Streams in the "riparian/floodplain preservation" category (RRRM and RRSM) drain watersheds with newer development (after 2000), upland infiltration wetlands, and $100 \mathrm{~m}$ wide undeveloped floodplains (Baltimore County Department of Planning, 2010). Sanitary sewers were constructed in these watersheds between 2000 and 2010 (Baltimore County Department of Planning, 2010). Sites in the "septic systems" category (RRSM and RRSD) drain lower density development with stormwater management in the form of stormwater sewer pipes (Fig. 1). All eight first-order stream sites were sampled every 2 weeks for dissolved carbon and nitrogen concentrations.

\subsubsection{Temporal sampling of dissolved gases and stream chemistry}

Headwater stream sites were sampled every 2 weeks for solutes (DOC; total dissolved nitrogen, TDN; humification index, HIX; and biological autochthonous inputs index, BIX) and dissolved gas $\left(\mathrm{CO}_{2}, \mathrm{CH}_{4}\right.$ and $\left.\mathrm{N}_{2} \mathrm{O}\right)$ concentrations. Chemistry sampling took place for 2 years, between January 2013 and December 2014, and gas sampling took place between July 2013 and July 2014. Sites were visited between 09:00 and 14:00 local time. Five dissolved gas samples were collected per stream on each date, along an established $20 \mathrm{~m}$ study reach either upstream or adjacent to the gaging station. Gas samples were collected at $0,5,10,15$, and $20 \mathrm{~m}$ 
Table 1. Summary of site characteristics including drainage area $\left(\mathrm{km}^{2}\right)$, percent impervious cover (\% IC), and percent of the watershed drained by GI stormwater best management practices (i \% GI SWM drainage).

\begin{tabular}{|c|c|c|c|c|c|}
\hline $\begin{array}{l}\text { Infrastructure } \\
\text { feature }\end{array}$ & Site & $\begin{array}{l}\text { Drainage area } \\
\left(\mathrm{km}^{2}\right)\end{array}$ & $\begin{array}{l}\% \mathrm{IC} \\
\text { cover }\end{array}$ & $\begin{array}{l}\% \text { GI SWM } \\
\text { drainage }\end{array}$ & Description \\
\hline \multirow[t]{2}{*}{$\begin{array}{l}\text { Septic } \\
\text { systems }\end{array}$} & RRSD & 0.23 & 7.9 & 0.00 & $\begin{array}{l}\text { Low-density residential development with septic sys- } \\
\text { tems, minimal stormwater management with some } \\
\text { stream burial. }\end{array}$ \\
\hline & RRSM & 0.68 & 3.78 & 13.97 & \\
\hline \multirow[t]{2}{*}{$\begin{array}{l}\text { Floodplain } \\
\text { preservation }\end{array}$} & RRRM & 0.63 & 16.4 & 100.00 & $\begin{array}{l}\text { Suburban and commercial low-impact development } \\
\text { converted from agriculture in early } 2000 \text { s. Stormwa- } \\
\text { ter wetlands in upland + wide riparian buffer zones sur- } \\
\text { round each stream and sanitary sewer infrastructure. }\end{array}$ \\
\hline & RRRB & 0.21 & 22.81 & 54.67 & \\
\hline \multirow[t]{2}{*}{$\begin{array}{l}\text { Inline SWM } \\
\text { wetlands }\end{array}$} & DRKV & 0.31 & 39.16 & 100.00 & $\begin{array}{l}\text { Older suburban development (1950s) with GI located } \\
\text { inline with stream channels, rather than dispersed } \\
\text { across the landscape. Watershed is serviced by sanitary } \\
\text { sewers. }\end{array}$ \\
\hline & DRGG & 0.6 & 36.68 & 47.60 & \\
\hline \multirow[t]{2}{*}{$\begin{array}{l}\text { Stream } \\
\text { burial }\end{array}$} & DRAL & 0.26 & 41.9 & 1.10 & $\begin{array}{l}\text { Older suburban and commercial development (1950s) } \\
\text { with piped headwaters upstream of the sampling point. } \\
\text { Watershed is serviced by sanitary sewers. No manage- } \\
\text { ment of stormwater other than the pipe network, which } \\
\text { also contains buried streams. }\end{array}$ \\
\hline & DRIS & 0.18 & 30.57 & 0.00 & \\
\hline
\end{tabular}

from the fixed starting point of the study reach. Samples were collected by submerging a $140 \mathrm{~mL}$ syringe with a three-way Luer lock and pulling $115 \mathrm{~mL}$ of stream water into the syringe. We added $25 \mathrm{~mL}$ of ultra-high purity helium to the syringe in the field and then shook the syringes vigorously for $5 \mathrm{~min}$ to promote equilibration of gases between aqueous and gas phases. After equilibration, $20 \mathrm{~mL}$ of the headspace was immediately transferred into a pre-evacuated glass vial capped with a screw-top rubber septum (LabCo Limited, Lampeter, UK) and then transported to the laboratory, where samples were stored at room temperature for up to 4 weeks prior to analyses. Water temperature and barometric pressure during the equilibration were recorded in the field. We collected three helium headspace blanks by injecting $25 \mathrm{~mL}$ of helium into pre-evacuated vials in the field.

We collected stream water samples in a $250 \mathrm{~mL}$ highdensity polyethylene bottles, one sample per site. One duplicate sample was collected on each sampling date, and the site for duplicate sample collection rotated among the sampling dates. Dissolved oxygen (DO) concentration and $\mathrm{pH}$ were measured at the upstream end of each study reach using a handheld YSI 550-A dissolved oxygen meter (YSI Inc., Yellow Springs, $\mathrm{OH}$ ) and an Oakton handheld $\mathrm{pH}$ meter (Oakton Instruments, Vernon Hills, IL).

\subsubsection{Longitudinal sampling of dissolved gases}

Longitudinal surveys were conducted in June 2012, March 2014, and December 2014 in Red Run and Dead Run. Longitudinal sampling started at the outlet of each major tributary (Dead Run or Red Run) and extended every $500 \mathrm{~m}$ upstream to include the four biweekly sampled headwater sites in each watershed (Fig. 1). During spring and fall months, solute and gas samples were collected along all major tributaries ( $>5 \%$ main stem flow) as well as every $500 \mathrm{~m}$ along the main stem of Dead Run and Red Run. Minor tributaries ( $<5 \%$ of main stem flow) were not sampled. Stream discharge was measured at each sampling point using a Marsh-McBirney Flo-Mate handheld velocity meter (Marsh-McBirney Inc., Frederick, MD, USA). We used cross-sectional measurements of stream velocity and water depth to calculate instantaneous discharge at each sampling site. We measured velocity and depth at a minimum of 10 points at each cross section in order to properly characterize flow across the channel. Discharge data were provided by USGS when sampling sites were co-located with a USGS gaging station (US Geological Survey, 2017).

We calculated the watershed contributing area above each sampling point and flow length from each sampling point to the watershed outlet using the "Hydrology" toolbox in ArcMap 10. Sampling locations were designated pour points in the hydrology tools workflow. Because sampling points 
were always co-located with road crossings, we were able to acquire the latitude and longitude of sampling sites using Google Earth software (Google Inc., 2009). Watersheds were delineated using a $2 \mathrm{~m}$ resolution digital elevation model (DEM; Baltimore County Government, 2002). We first corrected the DEM for spurious depressions using the "Fill" tool in the ArcMap10.0 Hydrology toolbox. Next, we calculated flow direction for each pixel of this filled DEM raster. We then used the "Flow Accumulation" tool to evaluate the number of pixels contributing to each downstream pixel. After ensuring that each pour point was co-located on the map streams (i.e., areas with flow accumulation $>500$ pixels), we used the "Watershed" tool to delineate the pixels draining into each sampled location.

\subsection{Laboratory methods}

\subsubsection{Dissolved gas concentrations}

Samples of headspace equilibrated gas concentrations $\left(\mathrm{CO}_{2}\right.$, $\mathrm{CH}_{4}$, and $\mathrm{N}_{2} \mathrm{O}$ ) were stored at room temperature for up to 1 month in airtight exetainer vials and transported to the EPA National Risk Management Research Laboratory, Cincinnati, Ohio, for analysis. Concentrations of $\mathrm{CO}_{2}, \mathrm{CH}_{4}$, and $\mathrm{N}_{2} \mathrm{O}$ were measured using a Bruker 450 (Bruker, Billerica, MA, USA) gas chromatograph equipped with a methanizer, flame ionization detector, and electron capture detector. Instrument detection limits were $100 \mathrm{ppb}$ for $\mathrm{N}_{2} \mathrm{O}, 10 \mathrm{ppm}$ for $\mathrm{CO}_{2}$, and $0.1 \mathrm{ppm}$ for $\mathrm{CH}_{4}$.

\subsubsection{Solute concentrations}

Water samples were transported on ice to the University of Maryland, College Park, and filtered using pre-combusted $0.7 \mu \mathrm{m}$ glass fiber filters within $24 \mathrm{~h}$. A Shimadzu TOC analyzer (Shimadzu Scientific, Kyoto, Japan) was used to measure total dissolved nitrogen and dissolved organic carbon. The non-purgeable organic carbon (NPOC) method was utilized for DOC, despite potential underestimation of volatile compounds because the NPOC method is insensitive to variations in dissolved inorganic carbon (DIC; Findlay et al., 2010). TDN was measured on the same instrument using the "TDN" method, which consists of high-temperature combustion in the presence of a platinum catalyst. Nitrate $\left(\mathrm{NO}_{3}^{-}\right)$ concentrations were measured via colorimetric reaction using a cadmium reduction column (Lachat method 10-10704-1-A) on a Lachat flow injection analyzer (Hach, Loveland, $\mathrm{CO}$ ).

\subsubsection{DOM characterization}

Filtered water samples were analyzed for optical properties in order to characterize dissolved organic matter (DOM) sources. After filtering $(0.7 \mu \mathrm{m} \mathrm{GF} / \mathrm{F}$ filter grade), samples were stored in amber glass vials at $4{ }^{\circ} \mathrm{C}$ for a maximum of 2 weeks prior to analyses. The detailed methodology for opti- cal properties and fluorescence indices can be found in Smith and Kaushal (2015), and numerous other studies have followed a similar filtration and storage procedure (Singh et al., 2014, 2015; Huguet et al., 2009; Dubnick et al., 2010; Gabor et al., 2014). Fluorescently active DOM constitutes a wide range of lability. While some highly labile compounds may break down within hours of sample collection, more recalcitrant forms can remain stable for months. The 2-week window is a convention meant to facilitate comparisons between sites, rather than a biologically based limit to storage (R. Gabor and S. Duan, personal communication, 2017). Briefly, fluorescence and absorbance properties of DOM were measured in order to evaluate the relative abundance of terrestrial and aquatic sources to the overall DOM pool.

A FluoroMax-4 Spectrofluorometer (Horiba Jobin Yvon, Edison, NJ, USA) was used to measure the emission spectra of samples in response to a variety of excitation wavelengths. Excitation-emission matrices (EEMs) were used for characterizing indices of terrestrial vs. aquatic DOM sources. The humification index is defined as the ratio of emission intensity of the $435-480 \mathrm{~nm}$ region of the EEM to the emission intensity of the $300-345 \mathrm{~nm}$ region of the EEM at the excitation wavelength of $254 \mathrm{~nm}$ (Zsolnay et al., 1999; Ohno, 2002). HIX varies from 0 to 1 , with higher values signifying high-molecular-weight DOM molecules characteristic of humic terrestrial sources. Lower HIX indicates DOM of bacterial or aquatic origin (Zsolnay et al., 1999). The biological autochthonous inputs index is defined as the ratio of fluorescence intensity at the emission wavelength $380 \mathrm{~nm}$ to the intensity emitted at $430 \mathrm{~nm}$ at the excitation wavelength of $310 \mathrm{~nm}$ (Huguet et al., 2009). Lower BIX values $(<0.7)$ represent terrestrial sources, and higher BIX values $(>0.8)$ represent algal or bacterial sources (Huguet et al., 2009).

\subsection{Calculations}

Dissolved gas concentrations were calculated using Eqs. (1)(3). First, we used Henry's law to convert measured mixing ratios (ppmv) to the molar concentration of each gas in the headspace vial $[\mathrm{Cg}]\left(\mu \mathrm{mol} \mathrm{L}^{-1}\right)$ following Eq. (1):

$[C]=\frac{P V}{R T}$,

where $P$ is pressure ( $1 \mathrm{~atm}), V$ is the measured partial pressure of the gas of interest (ppmv), $R$ is the universal gas constant $\left(0.0821 \mathrm{~L} \mathrm{~atm} \mathrm{~mol}^{1} \mathrm{~K}^{-1}\right)$, and $T$ is the temperature of a water sample (Kelvin) during headspace equilibration. We used Henry's law and a temperature-corrected Bunsen solubility coefficient to calculate $\left[C_{\mathrm{aq}}\right]$, which is the concentration of residual gas remaining in water following headspace equilibration (Eq. 2; Stumm and Morgan, 1981):

$\left[C_{\mathrm{aq}}\right]=\frac{V \cdot \mathrm{Bp} \cdot \text { Bunsen }}{R T}$,

where $V$ is measured gas mixing ratio (ppmv), Bp is the barometric pressure (atm), and Bunsen is the solubility coefficient 
in the vessel $\left(\mathrm{LL}^{-1}\right.$ at $\left.1 \mathrm{~atm}\right)$. Calculations of the Bunsen coefficient were based on Weiss (1974) for $\mathrm{CO}_{2}$, Weiss (1970) for $\mathrm{N}_{2} \mathrm{O}$, and Yamamoto et al. (1976) for $\mathrm{CH}_{4}$.

The final stream water concentration $\left[C_{\mathrm{str}}\right]$ was then calculated using mass balance of these two pools, described in Eq. (3), where $V_{\mathrm{aq}}$ and $V_{\mathrm{g}}$ were the volumes of water and gas respectively in a water sample with helium headspace.

$\left[C_{\mathrm{str}}\right]=\frac{\left[C_{\mathrm{aq}}\right] \cdot V_{\mathrm{aq}}+\left[C_{\mathrm{g}}\right] \cdot V_{\mathrm{g}}}{R T}$

Because gas solubility is temperature dependent, it was useful to display gas concentrations as the percent saturation, or the ratio of the measured dissolved gas concentration to the equilibrium concentration. To determine gas saturation, the equilibrium concentration, $\left[C_{\text {eq }}\right]$, was calculated based on water temperature, atmospheric pressure, and an assumed value for the current atmospheric mixing ratios of each gas following Eq. (2). We obtained current ratios for $\mathrm{CO}_{2}$ from The Keeling Curve (Scripps Institution of Oceanography, 2017) and $\mathrm{N}_{2} \mathrm{O}$ and $\mathrm{CH}_{4}$ from the NOAA Earth Systems Research Laboratory (NOAA ESRL, 2017; Dlugokencky, 2017). The saturation ratio is defined as a ratio $\left[C_{\mathrm{str}}\right] /\left[C_{\mathrm{eq}}\right]$, and excess (i.e., $x s \mathrm{CO}_{2}$ ) is described as a mass difference $\left(\left[C_{\mathrm{str}}\right]-\left[C_{\mathrm{eq}}\right]\right)$. Supersaturation is the condition when the saturation ratio is greater than 1 or gas excess (i.e., $x s \mathrm{CO}_{2}$ ) is greater than 0 .

\subsubsection{Apparent oxygen utilization}

Apparent oxygen utilization (AOU) is defined as the difference between the $\mathrm{O}_{2}$ concentrations $(\mu \mathrm{M})$ at equilibrium with the atmosphere vs. ambient measured $\mathrm{O}_{2}$ concentrations in the stream. A positive value of AOU represents net oxygen consumption conditions along the soil-groundwaterstream flow path, while a negative AOU $(\mu \mathrm{M})$ represents net $\mathrm{O}_{2}$ production within the stream. Because aerobic respiration and photosynthesis couples $\mathrm{CO}_{2}$ production and $\mathrm{O}_{2}$ consumption, we can assume that $\mathrm{AOU}$ is equivalent to the $\mathrm{CO}_{2}$ produced/consumed along the same flow path (Richey et al., 1998). Under aerobic conditions, respiration of organic matter consumes $\mathrm{O}_{2}$ and produces $\mathrm{CO}_{2}$ at approximately a $1: 1$ molar ratio (Schlesinger, 1997). Therefore, $1 \mathrm{~mol}$ of AOU should result in $1 \mathrm{~mol}$ of $x_{s} \mathrm{CO}_{2}$ (measured minus equilibrium $\mathrm{CO}_{2}$ concentration). This ratio was then used, with an offset to 1.2:1 to account for differences in diffusion constants for the two gases (Stumm and Morgan, 1981; Richey et al., 1988), to determine the proportion of $\mathrm{CO}_{2}$ produced by aerobic respiration. When $\mathrm{CO}_{2}$ concentrations are greater than $\mathrm{AOU}$, the difference between measured $\mathrm{CO}_{2}$ and $\mathrm{AOU}\left(x s \mathrm{CO}_{2}-\mathrm{AOU}\right)$ represents additional sources from either anaerobic respiration or abiotic sources. We split our analysis of $\mathrm{CO}_{2}$ into these two categories (AOU and $x s \mathrm{CO}_{2}-\mathrm{AOU}$ ) in order to determine whether patterns in $\mathrm{CO}_{2}$ saturation were solely represented by aerobic respiration or other processes and sources as well.

\subsubsection{Greenhouse gas emissions}

We calculated the gas flux rate using Eq. (4), where $F_{\mathrm{GT}}$ is the flux $\left(\mathrm{g} \mathrm{m}^{-2} \mathrm{~d}^{-1}\right)$ of a given gas $(G)$ at ambient temperature $(T)$ and $d$ is water depth $(\mathrm{m}) . K_{\mathrm{GT}}\left(\mathrm{d}^{-1}\right)$ is the reaeration coefficient for a given $G$ at ambient $T$. Measured and equilibrium gas concentrations $\left[C_{\mathrm{str}}\right]$ and $\left[C_{\mathrm{eq}}\right]$ were calculated following Eqs. (3) and (4) and then converted to units of $\mathrm{g} \mathrm{m}^{-3}$.

$F_{\mathrm{GT}}=K_{\mathrm{GT}} \cdot d \cdot\left(\left[C_{\mathrm{str}}\right]-\left[C_{\mathrm{eq}}\right]\right)$

We modeled $K_{\mathrm{GT}}$ for each site and sampling date using the energy dissipation model (Tsivoglou and Neal, 1976). The energy dissipation model predicts $\mathrm{K}$ from the product of water velocity $\left(V, \mathrm{~m} \mathrm{~d}^{-1}\right)$, water surface gradient $(S)$, and the escape coefficient, $C_{\text {esc }}\left(\mathrm{m}^{-1}\right.$; Eq. 5).

$K=C_{\mathrm{esc}} \cdot S \cdot V$

$C_{\text {esc }}$ is a parameter related to additional factors other than streambed slope and velocity that affect gas exchange, such as streambed roughness and the relative abundance of pools and riffles. The $C_{\text {esc }}$ value used in this study was derived from 22 measurements of $\mathrm{K}$, made using the $\mathrm{SF}_{6}$ gas tracer method, carried out across a range of flow conditions in four streams within $5 \mathrm{~km}$ of our study sites and reported in Pennino et al. (2014). $C_{\text {esc }}$ was calculated as the slope of the regression of K vs. $S \cdot V$ from data in Pennino et al. (2014) and was assumed to be representative of our headwater stream sites in Dead Run and Red Run.

We calculated $C_{\text {esc }}$ to be $0.653 \mathrm{~m}^{-1}\left(n=22, r^{2}=0.42\right.$, $p=0.001)$. The $95 \%$ confidence interval of this $C_{\text {esc }}$ based on measured $K_{20, \mathrm{O}_{2}}$ values was $\pm 0.359 \mathrm{~m}^{-1}$, which corresponds to $\pm 55 \%$ of a given gas flux estimate. This estimate of $C_{\text {esc }}$ from these nearby sites was assumed to be representative of the eight stream reaches investigated in this study. Given the moderate range of uncertainty in $C_{\mathrm{esc}}$, as well as additional uncertainties associated with slope estimation and relating $C_{\text {esc }}$ to different stream sites, gas flux estimates must be interpreted with caution.

Measurements of $\mathrm{K}$ were converted to $\mathrm{K}$ for each GHG (as well as $\mathrm{O}_{2}$ for general comparisons) by multiplying by the ratio of their Schmidt numbers (Stumm and Morgan, 1981). $K$ measured at ambient temperature $\left(K_{T}\right)$ was converted to $\mathrm{K}\left(\mathrm{d}^{-1}\right.$ at $20^{\circ} \mathrm{C}\left(K_{20}\right)$ following Eq. (6).

$K_{20}=\frac{K_{T}}{1.0421^{T-20}}$

In order to compare re-aeration rates across sites and prior studies, we calculated the gas transfer velocity, $k_{600}$, which is defined as $K_{20, \mathrm{O}_{2}}$ multiplied by water depth, with units of $\mathrm{md}^{-1}$.

We estimated $S$ of headwater streams with GHG sampling sites by measuring the change in elevation along the 
stream above and below stream gaging stations. We determined the latitude and longitude of the stream gage, which was co-located with GHG sampling sites in Red Run and Dead Run using a Trimble GeoXH handheld 3.5G edition GPS unit $(10 \mathrm{~cm}$ accuracy). We then plotted this location atop a $1 \mathrm{~m}$ resolution lidar-based DEM (Baltimore County Government, 2002) in ArcMap 10. Using low points in the DEM to represent the stream channel, we then selected one point above and one point below the stream gaging station and measured the distance between these two points along the stream channel with the "Measure" tool. We calculated $S$ based on the change in elevation divided by distance. The slope measurement reach overlapped with, but did not coincide exactly with, the gas sampling reach in order to ensure measurable differences in elevation. We followed the same protocol to estimate $S$ for reaches in Pennino et al. (2014), except, rather than estimating points above and below a gaging station, we determined the change in elevation over the specific reach where $\mathrm{SF}_{6}$ injections took place. Pennino et al. (2014) provided data on the latitude and longitude of their $\mathrm{SF}_{6}$ injection reaches.

Pennino et al.'s (2014) measurements of $V$ during gas injections ranged from 0.02 to $0.15 \mathrm{~m} \mathrm{~s}^{-1}$. $V$ measured at headwater gaging stations in our sites ranged from undetectable to $0.34 \mathrm{~m} \mathrm{~s}^{-1}$. In order to avoid extrapolation, we limited our estimation of gas fluxes to sampling sites and dates with $V$ in the range measured by Pennino et al. (2014). These conditions corresponded to 37 measurements in total, which were spread unevenly across the four headwater sites with complete rating curves (DRAL, DRKV, RRRB, DRGG). K estimates were restricted to 5 dates at DRAL, 18 dates at DRKV, 11 dates at RRRB, and 3 dates at DRGG.

\subsection{Statistical analyses}

\subsubsection{Role of infrastructure and seasonality}

A linear mixed effects modeling approach was used to determine the significant drivers of each gas across streams in different headwater infrastructure categories. Due to uncertainties in the gas flux parameters, GHG saturation ratios were used rather than GHG emissions to compare spatial and temporal patterns across sites. Mixed effects modeling was carried out using R (R Core Team, 2014) and the "nlme" package (Pinheiro et al., 2012) following guidance outlined in Zurr et al. (2009). Separate mixed effects models were used to detect the role of infrastructure category and date on each response variable. Response variables included saturation ratios for each gas $\left(\mathrm{CO}_{2}, \mathrm{~N}_{2} \mathrm{O}\right.$, and $\left.\mathrm{CH}_{4}\right)$, solute concentrations (DOC, DIC, TDN, and $\mathrm{NO}_{3}^{-}$), and organic matter source indices (HIX and BIX). Fixed effects were "infrastructure category" and "sampling date" as well as an interaction term for the two. The effect of a random intercept for "site" was included in each model. The statistical assumptions of normality and equal variances were validated by inspecting model residuals. When necessary, variances were weighted based on infrastructure category to remove heteroscedasticity in model residuals (Zuur et al., 2009). The assumption of temporal independence was examined by testing for temporal autocorrelation in each response variable. This test was performed using the function "corAR1", which is part of the package "nlme" in R. The significance of random effects, weighting variances, and temporal autocorrelation was tested by comparing Akaike information criterion (AIC) scores for models with and without each of these attributes. Additionally, pairwise ANOVA tests were run to determine whether each additional level of model complexity significantly reduced the residual sum of squares. Final model selection was based on meeting model assumptions, minimizing the AIC value, and minimizing the residual standard error. Pairwise comparisons among infrastructure categories were examined using the Tukey HSD post-hoc test ("lsmeans" package, Lenth, 2016) for each response variable where "infrastructure category" had a significant effect. Where "infrastructure category" did not have a significant effect on a response variable after incorporating "site" as a random effect, a separate set of linear models was run with "site" and "date" as main effects rather than "infrastructure category". The role of "site" was evaluated in these cases to determine the degree to which site-specific factors overwhelmed the effect of infrastructure category.

\subsection{Role of environmental variables on gas saturation}

A stepwise linear regression approach was used to examine the role of multiple environmental variables on $\mathrm{CO}_{2}, \mathrm{~N}_{2} \mathrm{O}$, and $\mathrm{CH}_{4}$ saturation across sites and dates. Predictor variables were selected via a backward stepwise procedure, using the "Step" function in R. This involves first running a model that includes all potential driving factors and then running sequential iterations of that model after removing one variable at a time until the simplest and most robust combination of predictors was achieved. Model fit at each step was evaluated using the AIC score. Parameters that did not reduce AIC when comparing models were removed until the model had the best fit with the minimum number of factors. The initial list of potential drivers included temperature, DO, DOC, TDN, DIC, HIX, and the BIX. Prior to the stepwise regression, we calculated the variance inflation factor (VIF) for each response variable to test for multicolinearity. VIF $>3$ was the cut off for assessing multicolinearity. All variables in this study were below the VIF $>3$ threshold (Zuur et al., 2010).

Analysis of covariance (ANCOVA) was carried out to determine whether relationships among gases $\left(\mathrm{CO}_{2}\right.$ vs. $\mathrm{N}_{2} \mathrm{O}$ and $\mathrm{CO}_{2}$ vs. $\mathrm{CH}_{4}$ ) and solutes (log of DOC : $\mathrm{NO}_{3}^{-}$ratio) varied systematically across infrastructure categories. ANCOVA involved comparing two generalized least squares models. The first linear model included an interaction term between one of the predictor variables (i.e., DOC or $\mathrm{CO}_{2}$ ) and in- 
frastructure category to predict the response variable $\left(\mathrm{N}_{2} \mathrm{O}\right.$ or $\mathrm{CH}_{4}$ ). The second was a linear model with the same two independent variables but no interaction term. When infrastructure category had a significant influence on both the intercept (first model) and slope (second model) of a relationship, this refuted the null hypothesis that infrastructure category had no influence on a relationship.

Because we used three separate models to evaluate variations in three GHG concentrations (for across infrastructure categories, continuous variables, and ANCOVA), we used a Bonferroni correction for the $95 \%$ confidence level. We determined the new confidence level by dividing the $95 \%$ level $(0.05)$ by the number of models used on all gases across headwater stream sites (6). This new $p$ value $(0.008)$ was then used to determine significance rather than 0.05 .

\subsubsection{Longitudinal variability in gas saturation}

We analyzed longitudinal data using multiple linear regressions in order to evaluate whether patterns observed in headwater sites were representative of the broader stream network. We compiled data from four surveys - Red Run and Dead Run in spring and fall - and used a stepwise linear regression approach to determine the significant drivers for each gas (Table 6). Covariates included the log of drainage area above each point, watershed (Red Run vs. Dead Run), season (spring vs. fall), DOC concentration, DIC concentration, TDN concentration, log of discharge, location (tributary vs. main stem), DOC: TDN molar ratio, a TDN by drainage area interaction term, and a DOC by drainage area interaction term. We used the stepAIC function in R to determine the optimal model formulation, selecting the model with minimum AIC.

\section{Results}

\subsection{Effect of infrastructure on water quality and DOC : $\mathrm{NO}_{3}^{-}$ratios}

We detected significant differences among $\mathrm{TDN}, \mathrm{NO}_{3}^{-}$, and DOC : $\mathrm{NO}_{3}^{-}$ratios across infrastructure categories (Table 2). TDN concentrations ranged from 0.12 to $8.7 \mathrm{mg} \mathrm{N} \mathrm{L}^{-1}$ (Table 3). Pairwise comparisons yielded significantly higher TDN concentrations in sites in the typology of "septic systems", compared with the "inline SWM wetlands" typology, and sites in the "riparian/floodplain preservation" typology. Sites in the "stream burial" typology fell within the midrange of TDN concentrations and were not different from any other category. DOC concentrations varied widely from 0.19 to $16.89 \mathrm{mg} \mathrm{L}^{-1}$ but were not significantly predicted by infrastructure typology (Table 2). $\mathrm{DOC}: \mathrm{NO}_{3}^{-}$ratios varied over 4 orders of magnitude, from 0.02 to 112 (Fig. 2). Infrastructure typology was a significant predictor of DOC : $\mathrm{NO}_{3}^{-}$, with the lowest ratios in sites with septic systems and highest

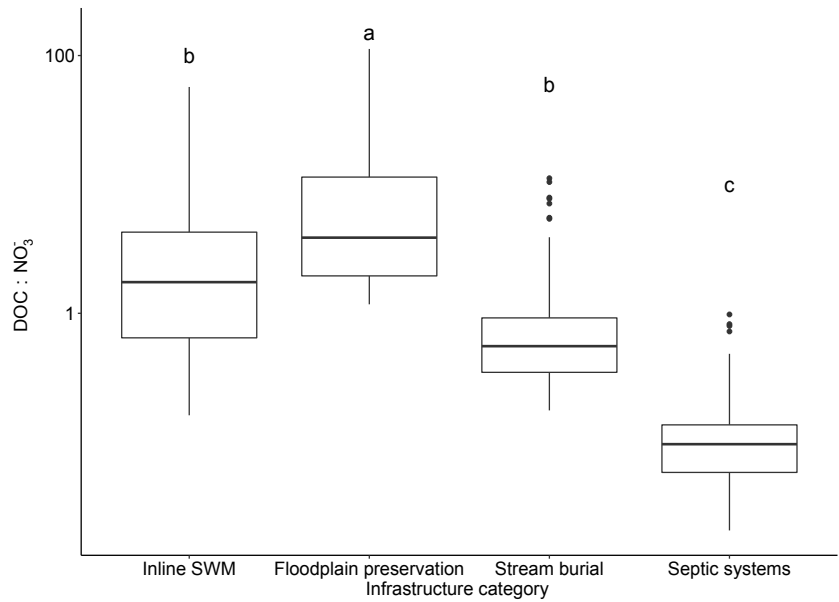

Figure 2. Boxplot of molar DOC: $\mathrm{NO}_{3}^{-}$ratio across sites in watersheds with differing infrastructure typologies. The median of each dataset is signified by the middle horizontal line for each category. Boxes signify the range between the first and third quartiles (25th and 75th percentiles). Vertical lines extend to the minimum and maximum points in the dataset that are within 1.5 times the interquartile range. Points signify data that fall above or below this range. Letters represent significant $(p<0.01)$ differences between infrastructure typologies for $\mathrm{DOC}: \mathrm{NO}_{3}^{-}$across all sampling dates, determined using a linear mixed effects model.

in sites with riparian/floodplain preservation (Fig. 2). Pairwise comparisons showed no difference in $\mathrm{DOC}: \mathrm{NO}_{3}^{-}$ratios between in the inline SWM wetland and complete stream burial typologies, however (Fig. 2).

\subsection{Effect of urban infrastructure on DOM quality}

Measurements of HIX ranged from 0.30 to 0.90 , while BIX ranged from 0.40 to 1.15 across all sites and sampling dates in headwater streams. Streams draining septic system infrastructure had significantly lower HIX values than any other infrastructure typology. BIX values showed no significant pattern across infrastructure typologies (Table 2).

\subsection{Effect of urban infrastructure on gas concentrations}

Mixed effects models did not detect significant influence of infrastructure typology alone on $\mathrm{CO}_{2}, \mathrm{CH}_{4}$, and $\mathrm{N}_{2} \mathrm{O}$ saturation in streams. There was, however, a significant interaction effect between sampling date and infrastructure typology on the saturation ratios of all three gases (Table 2). This indicated that sampling date was important to GHG saturation for some infrastructure typologies or that the effect of infrastructure is dependent upon sampling date. The second set of linear models, which used site rather than infrastructure category as a main effect, yielded significant differences across all sites for $\mathrm{N}_{2} \mathrm{O}$ (Fig. 3). Similarly, for $\mathrm{CO}_{2}$, there were significant differences in 25 out of 28 pairwise comparisons. 
Table 2. Summary of results (main effects $p$ values) from mixed effects models examining the role of infrastructure typology and date on the following response variables: $\mathrm{CO}_{2}, \mathrm{~N}_{2} \mathrm{O}$, and $\mathrm{CH}_{4}$ saturation ratios; TDN and DOC concentrations (mg L ${ }^{-1}$ ), BIX, and $\mathrm{HIX}$ (unitless).

\begin{tabular}{lllllllll}
\hline Main effects & $\mathrm{CO}_{2}$ & $\mathrm{CH}_{4}$ & $\mathrm{~N}_{2} \mathrm{O}$ & $\mathrm{TDN}$ & $\mathrm{DOC}$ & $\mathrm{BIX}$ & $\mathrm{HIX}$ & $\mathrm{DOC}^{\mathrm{NO}} \mathrm{NO}_{3}^{-}$ \\
\hline $\begin{array}{l}\text { Infrastructure typology } \\
p \text { value }\end{array}$ & 0.496 & 0.298 & 0.488 & 0.068 & 0.200 & 0.441 & 0.020 & $<0.008^{*}$ \\
Date $p$ value & 0.957 & $<0.008^{*}$ & $<0.008^{*}$ & 0.086 & 0.387 & 0.155 & 0.765 & 0.492 \\
Date by infrastructure typology & $<0.008^{*}$ & $<0.008^{*}$ & $<0.008^{*}$ & 0.114 & 0.978 & 0.490 & 0.899 & 0.894 \\
Interaction $p$ value & & & & & & & & \\
\hline
\end{tabular}

* indicate variables that are significant at the 0.008 level.

Table 3. Mean with standard error in parentheses of GHG saturation ratios, TDN and DOC concentrations (mg L ${ }^{-1}$ ), BIX values, and HIX values for each site.

\begin{tabular}{|c|c|c|c|c|c|c|c|c|c|}
\hline $\begin{array}{l}\text { Infrastructure } \\
\text { typology }\end{array}$ & Site & $\mathrm{CO}_{2}$ & $\mathrm{CH}_{4}$ & $\mathrm{~N}_{2} \mathrm{O}$ & TDN & DOC & BIX & HIX & $\mathrm{DOC}: \mathrm{NO}_{3}^{-}$ \\
\hline \multirow[t]{2}{*}{ Septic systems } & RRSD & $\begin{array}{l}52.9 \\
(1.1)\end{array}$ & $\begin{array}{l}14.9 \\
(0.5)\end{array}$ & $\begin{array}{l}28.0 \\
(0.7)\end{array}$ & $\begin{array}{l}6.40 \\
(0.20)\end{array}$ & $\begin{array}{l}0.76 \\
(0.12)\end{array}$ & $\begin{array}{l}0.89 \\
(0.02)\end{array}$ & $\begin{array}{l}0.74 \\
(0.01)\end{array}$ & $\begin{array}{l}0.06 \\
(0.01)\end{array}$ \\
\hline & RRSM & $\begin{array}{l}13.5 \\
(0.5)\end{array}$ & $\begin{array}{l}25.6 \\
(1.5)\end{array}$ & $\begin{array}{l}5.9 \\
(0.2)\end{array}$ & $\begin{array}{l}3.49 \\
(0.13)\end{array}$ & $\begin{array}{l}1.40 \\
(0.25)\end{array}$ & $\begin{array}{l}0.70 \\
(0.02)\end{array}$ & $\begin{array}{l}0.782 \\
(0.015)\end{array}$ & $\begin{array}{l}0.27 \\
(0.04)\end{array}$ \\
\hline \multirow[t]{2}{*}{$\begin{array}{l}\text { Riparian/floodplain } \\
\text { preservation }\end{array}$} & RRRM & $\begin{array}{l}6.6 \\
(0.3)\end{array}$ & $\begin{array}{l}207.3 \\
(36.2)\end{array}$ & $\begin{array}{l}1.7 \\
(0.04)\end{array}$ & $\begin{array}{l}0.59 \\
(0.08)\end{array}$ & $\begin{array}{l}2.89 \\
(0.27)\end{array}$ & $\begin{array}{l}0.67 \\
(0.01)\end{array}$ & $\begin{array}{l}0.85 \\
(0.02)\end{array}$ & $\begin{array}{l}12.16 \\
(3.45)\end{array}$ \\
\hline & RRRB & $\begin{array}{l}9.6 \\
(0.4)\end{array}$ & $\begin{array}{l}103.6 \\
(8.6)\end{array}$ & $\begin{array}{l}3.6 \\
(0.1)\end{array}$ & $\begin{array}{l}0.35 \\
(0.02)\end{array}$ & $\begin{array}{l}1.58 \\
(0.18)\end{array}$ & $\begin{array}{l}0.716 \\
(0.01)\end{array}$ & $\begin{array}{l}0.85 \\
(0.01)\end{array}$ & $\begin{array}{l}9.24 \\
(2.43)\end{array}$ \\
\hline \multirow[t]{2}{*}{ Inline SWM } & DRKV & $\begin{array}{l}28.1 \\
(1.0)\end{array}$ & $\begin{array}{l}50.8 \\
(8.5)\end{array}$ & $\begin{array}{l}19.1 \\
(0.6)\end{array}$ & $\begin{array}{l}2.52 \\
(0.16)\end{array}$ & $\begin{array}{l}2.65 \\
(0.24)\end{array}$ & $\begin{array}{l}0.75 \\
(0.01)\end{array}$ & $\begin{array}{l}0.86 \\
(0.003)\end{array}$ & $\begin{array}{l}2.38 \\
(0.67)\end{array}$ \\
\hline & DRGG & $\begin{array}{l}16.3 \\
(1.1)\end{array}$ & $\begin{array}{l}225.8 \\
(31.9)\end{array}$ & $\begin{array}{l}7.9 \\
(0.4)\end{array}$ & $\begin{array}{l}1.16 \\
(0.07)\end{array}$ & $\begin{array}{l}5.32 \\
(0.60)\end{array}$ & $\begin{array}{l}0.73 \\
(0.02)\end{array}$ & $\begin{array}{l}0.83 \\
(0.01)\end{array}$ & $\begin{array}{l}8.72 \\
(2.23)\end{array}$ \\
\hline \multirow[t]{2}{*}{ Stream burial } & DRAL & $\begin{array}{l}7.9 \\
(0.3)\end{array}$ & $\begin{array}{l}11.3 \\
(0.6)\end{array}$ & $\begin{array}{l}5.1 \\
(0.2)\end{array}$ & $\begin{array}{l}2.68 \\
(0.09)\end{array}$ & $\begin{array}{l}2.64 \\
(0.37)\end{array}$ & $\begin{array}{l}0.81 \\
(0.01)\end{array}$ & $\begin{array}{l}0.83 \\
(0.01)\end{array}$ & $\begin{array}{l}1.42 \\
(0.40)\end{array}$ \\
\hline & DRIS & $\begin{array}{l}22.6 \\
(1.0)\end{array}$ & $\begin{array}{l}78.4 \\
(5.8)\end{array}$ & $\begin{array}{l}10.7 \\
(0.5)\end{array}$ & $\begin{array}{l}2.42 \\
(0.09)\end{array}$ & $\begin{array}{l}2.51 \\
(0.27)\end{array}$ & $\begin{array}{l}0.79 \\
(0.01)\end{array}$ & $\begin{array}{l}0.82 \\
(0.01)\end{array}$ & $\begin{array}{l}1.82 \\
(0.44)\end{array}$ \\
\hline
\end{tabular}

Pairwise comparisons across sites for $\mathrm{CH}_{4}$ saturation were significant in 23 out of 28 cases. These patterns suggest that site-specific effects overwhelmed the role of infrastructure categories on GHG saturation.

\subsection{Effect of environmental variables on gas concentrations}

Stepwise model parameter selection yielded several variables that correlate with each GHG saturation ratio (Table 4). TDN was the strongest predictor of $\mathrm{N}_{2} \mathrm{O}$ saturation, followed by DO. The final model for $\mathrm{N}_{2} \mathrm{O}\left(r^{2}=0.78\right)$ also included temperature, HIX, BIX, \%SWM, and DOC : $\mathrm{NO}_{3}^{-} \cdot \mathrm{CO}_{2}$ saturation had a similar pattern of predictors and nearly identical model fit $\left(r^{2}=0.78\right)$. The DOC $: \mathrm{NO}_{3}^{-}$ratio was the strongest predictor of $\mathrm{CH}_{4}$ saturation followed by DO and temperature.
HIX, \% IC, and \%SWM were also related to $\mathrm{CH}_{4}$ saturation, but TDN and BIX were not.

\subsection{Covariance among GHG abundance and $\mathrm{C}: \mathrm{N}$ stoichiometry}

AOU ranged from -180.9 to 293.9 across all sites and sampling dates; however, AOU was only negative (net oxygen production along surface and subsurface flow paths) in $6 \%$ of samples, or 43 out of 691 measurements. $\mathrm{N}_{2} \mathrm{O}$ was significantly but weakly correlated with AOU $\left(p<0.008, r^{2}=0.12\right)$ and strongly correlated with $x \mathrm{SCO}_{2}$ AOU $\left(p<0.008, r^{2}=0.87\right)$. The $\log$ of $\mathrm{CH}_{4}$ saturation ratio was very weakly correlated with AOU $\left(p<0.008, r^{2}=0.01\right)$ as well as $x s \mathrm{CO}_{2}$-AOU $\left(p<0.008, r^{2}=0.07\right)$. The relationships between $x s \mathrm{CO}_{2}$-AOU and both $\mathrm{N}_{2} \mathrm{O}$ and $\mathrm{CH}_{4}$ saturation ratios were also significantly different between cate- 


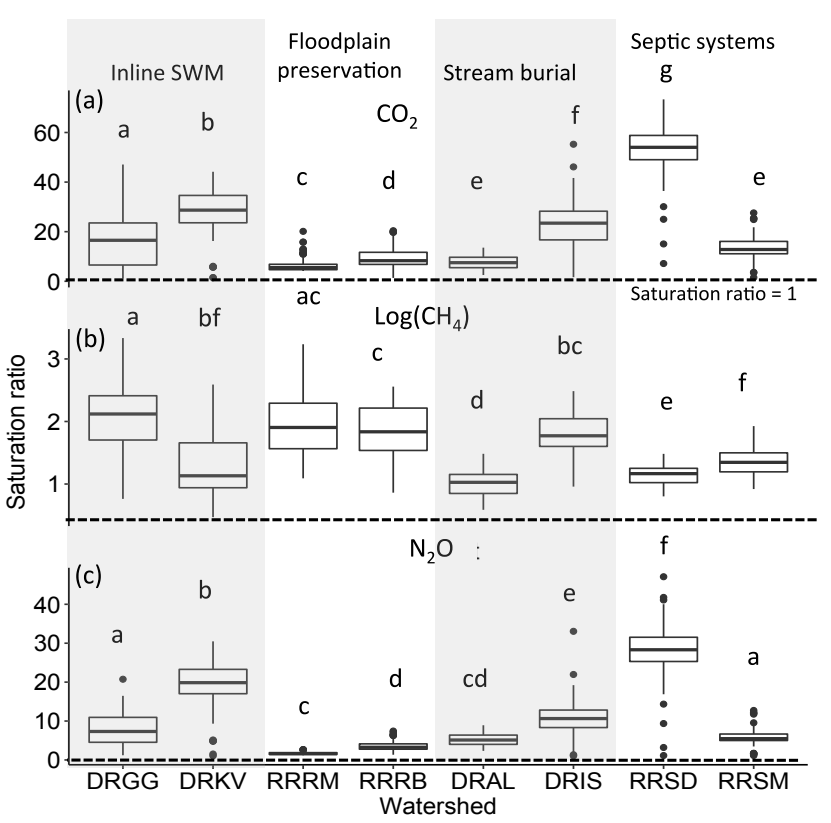

Figure 3. Boxplot of $\mathrm{CO}_{2}, \mathrm{CH}_{4}$, and $\mathrm{N}_{2} \mathrm{O}$ saturation ratios across stream sites in varying infrastructure categories. Letters denote significant pairwise differences across streams for a given gas from linear mixed effects models with "Watershed" as a main effect. Boxes signify the range between the first and third quartiles (25th and 75th percentiles). Vertical lines extend to the minimum and maximum points in the dataset that are within 1.5 times the interquartile range. Points signify outliers outside of 1.5 times the interquartile range.

Table 4. Main effects, model coefficients, adjusted $r^{2}$, and overall model $p$ value for stepwise regression models examining the relationship between continuous variables and GHG saturation ratios. The model coefficient is the main effect of each parameter, and the absolute value of this coefficient signifies the relative contribution of each predictor. $\mathrm{A}^{*}$ indicates the predictor with the greatest influence for each response variable $\left(\mathrm{CO}_{2}, \mathrm{CH}_{4}\right.$, and $\left.\mathrm{N}_{2} \mathrm{O}\right)$. Rows with "n.a." indicate that the predictor variable was not retained in the final model.

\begin{tabular}{llll}
\hline & $\mathrm{CO}_{2}$ & $\mathrm{CH}_{4}$ & $\mathrm{~N}_{2} \mathrm{O}$ \\
\hline Predictor & Coefficient & Coefficient & Coefficient \\
\hline TDN & $1.08^{*}$ & n.a. & $1.10^{*}$ \\
Temperature & -0.22 & 0.25 & -0.26 \\
DO & -0.46 & -0.27 & -0.37 \\
HIX & 0.09 & -0.15 & 0.13 \\
BIX & 0.11 & n.a. & 0.15 \\
$\%$ IC & n.a. & -0.16 & 0.14 \\
$\%$ SWM & 0.18 & 0.16 & 0.31 \\
$\log \left(\right.$ DOC $\left.: \mathrm{NO}_{3}^{-}\right)$ & 0.32 & $0.55^{*}$ & 0.19 \\
Overall model fit & & & \\
Adjusted $r^{2}$ & 0.78 & 0.5 & 0.78 \\
$P$ value & $<0.008^{*}$ & $<0.0008^{*}$ & $<0.008^{*}$ \\
\hline
\end{tabular}
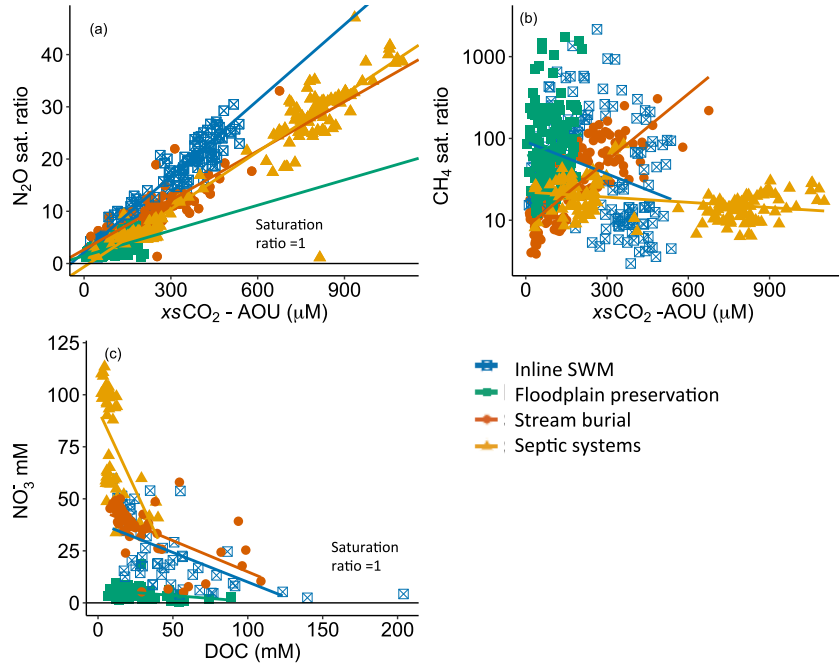

Figure 4. Scatterplots of (a) $\mathrm{N}_{2} \mathrm{O}$ saturation vs. $x s \mathrm{CO}_{2}-\mathrm{AOU}(\mu \mathrm{M})$, (b) $\mathrm{CH}_{4}$ saturation vs. anaerobic $\mathrm{CO}_{2}$, and (c) relationships between $\mathrm{NO}_{3}^{-}$and DOC. Lines denote significant $(p<0.01)$ correlations among gas or solute concentrations, which vary by infrastructure category.

gories (Fig. 4). There was an overall negative relationship between $\mathrm{DOC}$ and $\mathrm{NO}_{3}^{-}$, with a significant interaction with infrastructure category (Fig. 4c; ANCOVA, $p$ value $<0.008$ ).

\subsection{Longitudinal patterns in GHG saturation}

Spatial variability in GHG saturation was examined in order to evaluate whether concentrations measured in tributaries were consistent between headwaters and the larger third-order watersheds of Red Run and Dead Run respectively (Fig. 5). Multiple linear regressions yielded a set of distinct controlling factors on saturation of each gas. The optimal models for $\mathrm{CO}_{2}$ and $\mathrm{N}_{2} \mathrm{O}$ were similar and included the $\log$ of drainage area, TDN concentration, log of discharge, and TDN $\times$ discharge interaction term. The $\mathrm{CO}_{2}$ model also included the DOC: TDN molar ratio. The optimal model for $\mathrm{CH}_{4}$ saturation was slightly different and included the log of drainage area, season (spring vs. fall), DOC concentration, and DOC: TDN molar ratio (Table 6). TDN concentration was not included in the optimal model for $\mathrm{CH}_{4}$. Watershed location (tributary vs. main stem) was not included in the final model for any of the three gases.

\subsection{Greenhouse gas emissions}

GHG emission rates were sensitive to differences in modeled $k_{600}$. Despite having medium-to-low gas saturation ratios compared with other sites, DRKV had the highest GHG emission rates on all dates. This is due in part to having the highest slope $\left(0.10 \mathrm{~m} \mathrm{~m}^{-1}\right)$ and thus the highest modeled $k_{600}\left(\mathrm{~m} \mathrm{~d}^{-1}\right)$. Our 37 estimates of $k_{600}$ ranged from 2.4 to $122.6 .1 \mathrm{~m} \mathrm{~d}^{-1}$. Site-averages for $k_{600}$ varied from 

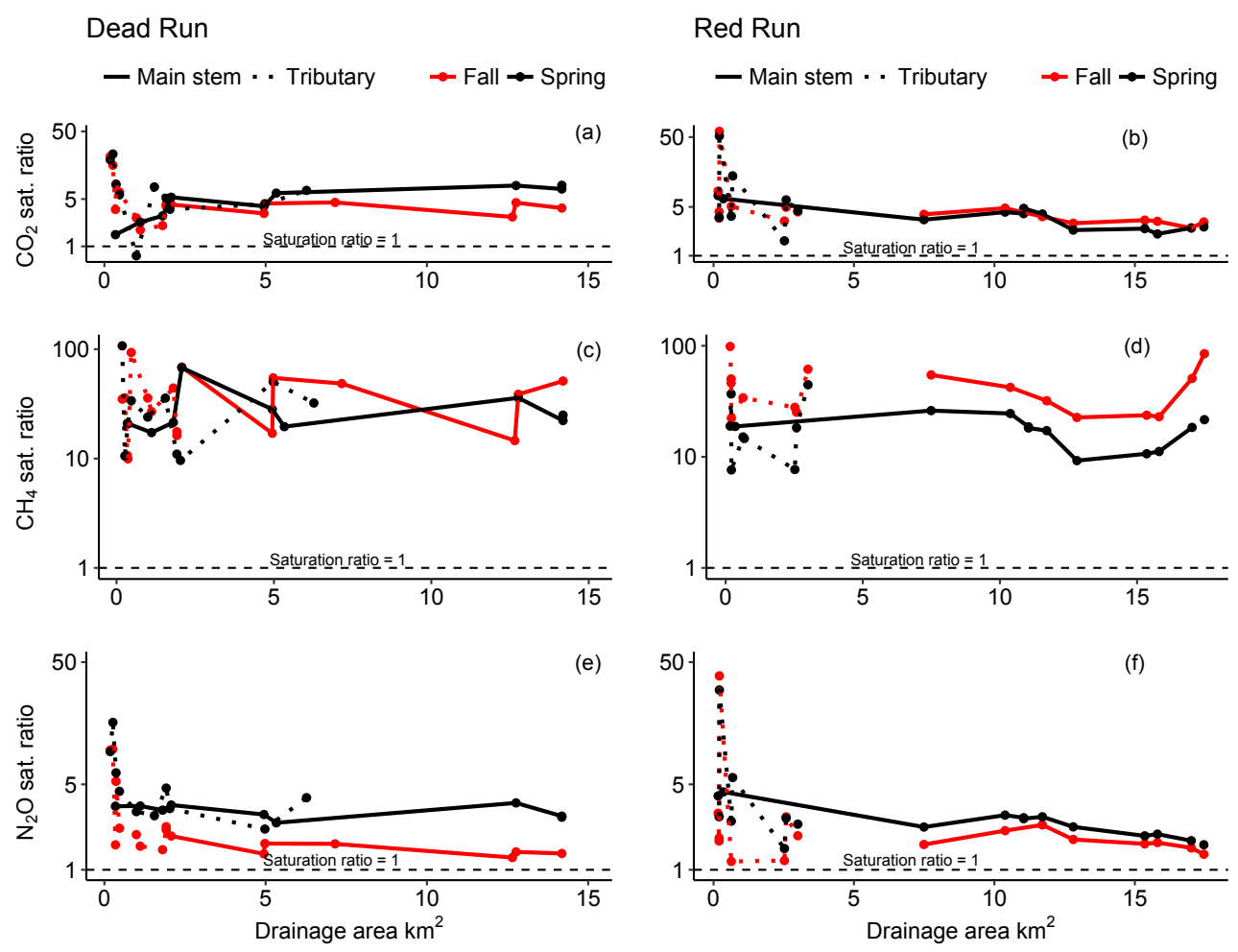

Figure 5. Longitudinal variability in $\mathrm{CO}_{2}(\mathbf{a}-\mathbf{b}), \mathrm{CH}_{4}(\mathbf{c}-\mathbf{d})$, and $\mathrm{N}_{2} \mathrm{O}(\mathbf{e}-\mathbf{f})$ saturation ratios from spring and fall synoptic surveys of Dead Run and Red Run. Dotted lines denote tributaries to each watershed, while straight lines denote the main stem sites.

$5.39 \pm 0.73$ to $28.0 \pm 7.0 \mathrm{~m} \mathrm{~d}^{-1}$. The median value for all $k_{600}$ estimates was $13.24 \mathrm{~m} \mathrm{~d}^{-1}$. This range of values and site-averaged values extends beyond that measured by Pennino et al. (2014) of 0.5 to $9.0 \mathrm{~m} \mathrm{~d}^{-1}$. The discrepancy between Pennino et al.'s (2014) $k_{600}$ measurements is driven by differences in channel gradient. Gradients in the present study ranged from 0.01 to 0.1 , while Pennino's ranged from 0.001 to $0.016 \mathrm{~m} \mathrm{~d}^{-1}$. Channel gradient $(S)$ is also the parameter with the greatest uncertainty, thus warranting cautious interpretation of our gas emission estimates.

Site-average $\mathrm{CO}_{2}$ emissions ranged from $6.4 \pm 2.3 \mathrm{~g} \mathrm{C} \mathrm{m}^{-2} \mathrm{~d}^{-1}$ at DRAL ( \pm standard error) to $134 \pm 30.2$ at DRKV. Mean emission rates for DRGG and RRRB were $11.5 \pm 6.1$ and $10.3 \pm 1.7$ respectively. Site-average $\mathrm{CH}_{4}$ emissions ranged from $2.6 \pm 1.1$ at DRAL to $102.5 \pm 75.6 \mathrm{mg} \mathrm{C} \mathrm{m}^{-2} \mathrm{~d}^{-1}$ at DRKV. $\mathrm{N}_{2} \mathrm{O}$ emissions ranged from $5.1 \pm 0.8$ at RRRB to $149 \pm 33.9 \mathrm{mg} \mathrm{N} \mathrm{m}^{-2} \mathrm{~d}^{-1}$ at DRKV. The full range of values and standard errors for fluxes are listed in Table 5.

\section{Discussion}

\subsection{Overview}

This study showed strong relationships between urban water quality and GHG saturation across streams draining dif- ferent forms of urban infrastructure. $\mathrm{N}_{2} \mathrm{O}$ and $\mathrm{CO}_{2}$ saturation was correlated with nitrogen concentrations but did not differ between infrastructure typologies. $\mathrm{DOC}: \mathrm{NO}_{3}^{-}$did differ among the four infrastructure categories, however (Table 2). While infrastructure categories did not show a significant predictor of GHG saturation in streams, the gradients in DOC : $\mathrm{NO}_{3}^{-}$found across all categories were strongly correlated with GHG saturation. Stoichiometric variation may thus serve as a predictor of GHG saturation downstream where land cover and infrastructure does not. While direct GHG loading to streams from leaky sanitary and/or stormwater infrastructure may play a role, the strongest predictors of GHGs in this study were continuous/environmental variables (i.e., TDN and DOC concentrations, DO, temperature), rather than categorical (infrastructure category). Relationships between anaerobic $x s \mathrm{CO}_{2}$-AOU and $\mathrm{N}_{2} \mathrm{O}$ saturation further suggest that anaerobic metabolism contributes to $\mathrm{N}_{2} \mathrm{O}$ production along hydrologic flow paths (Fig. 4).

\section{2 $\mathrm{C}: \mathrm{N}$ stoichiometry as an indicator of microbial metabolism}

By comparing various forms of infrastructure, results from this study support a growing understanding of the biogeochemical consequences of expanded hydrologic connectivity in urban watersheds. Strong inverse relationships between DOC and $\mathrm{NO}_{3}^{-}$present across all infrastructure categories 
Table 5. Summary of gas flux estimations for the four sites with continuous flow data. Average, standard error (SE), and number of measurements $(n)$ are listed for $\mathrm{CO}_{2}\left(\mathrm{~g} \mathrm{C} \mathrm{m}^{-2} \mathrm{~d}^{-1}\right), \mathrm{CH}_{4}\left(\mathrm{mg} \mathrm{C} \mathrm{m}^{-2} \mathrm{~d}^{-}\right), \mathrm{N}_{2} \mathrm{O}\left(\mathrm{mg} \mathrm{N} \mathrm{m}^{-2} \mathrm{~d}^{-}\right)$, and predicted $k_{600}\left(\mathrm{~m} \mathrm{~d}^{-1}\right)$.

\begin{tabular}{llllllll}
\hline Infrastructure typology & Site & Parameter & Minimum & Maximum & Mean & SE & $n$ \\
\hline Stream burial & DRAL & $\mathrm{CO}_{2}$ & 2.37 & 23.12 & 11.51 & 6.12 & 5 \\
Inline SWM & DRGG & & 53.28 & 548.01 & 134.55 & 30.18 & 3 \\
Inline SWM & DRKV & & 3.39 & 23.81 & 10.30 & 1.74 & 18 \\
Floodplain preservation & RRRB & & 0.61 & 5.51 & 2.55 & 1.10 & 11 \\
\hline Stream burial & DRAL & $\mathrm{CH}_{4}$ & 7.71 & 23.67 & 14.09 & 4.88 & 5 \\
Inline SWM & DRGG & & 2.27 & 1339.62 & 102.51 & 75.57 & 3 \\
Inline SWM & DRKV & & 3.26 & 62.98 & 16.80 & 5.29 & 18 \\
Floodplain preservation & RRRB & & 2.19 & 12.11 & 6.69 & 2.19 & 11 \\
\hline \multirow{2}{*}{ Stream burial } & DRAL & \multirow{2}{*}{$\mathrm{N}_{2}$} & 2.13 & 24.21 & 12.33 & 6.43 & 5 \\
Inline SWM & DRGG & & 60.45 & 565.17 & 149.63 & 33.91 & 3 \\
Inline SWM & DRKV & & 1.90 & 8.61 & 5.14 & 0.79 & 18 \\
Floodplain preservation & RRRB & & 2.57 & 16.98 & 7.03 & 2.63 & 11 \\
\hline Stream burial & DRAL & \multirow{2}{*}{$k 600$} & 3.84 & 19.20 & 10.97 & 4.47 & 5 \\
Inline SWM & DRGG & & 12.82 & 122.59 & 28.02 & 7.06 & 3 \\
Inline SWM & DRKV & & 2.40 & 8.89 & 5.39 & 0.73 & 18 \\
Floodplain preservation & RRRB & & 2.57 & 13.91 & 6.45 & 2.33 & 11 \\
\hline
\end{tabular}

Table 6. Covariates and model fit parameters for linear models describing drivers of gas saturation ratios $\left(\mathrm{CO}_{2}, \mathrm{CH}_{4}\right.$, and $\left.\mathrm{N}_{2} \mathrm{O}\right)$ from longitudinal surveys of Dead Run and Red Run. X's denote that a given parameter was used in the final model while dashes (-) denote that parameters were not used.

\begin{tabular}{lccc}
\hline Covariates tested & $\mathrm{CO}_{2}$ sat. ratio & $\mathrm{CH}_{4}$ sat. ratio & $\mathrm{N}_{2} \mathrm{O}$ sat. ratio \\
\hline Log of drainage area $\left(\mathrm{km}^{2}\right)$ & $\mathrm{X}$ & $\mathrm{X}$ & $\mathrm{X}$ \\
Watershed (Dead Run vs. Red Run) & - & - & - \\
Season & - & $\mathrm{X}$ & $\mathrm{X}$ \\
DOC $\left(\mathrm{mg} \mathrm{L}^{-1}\right)$ & - & $\mathrm{X}$ & - \\
DIC $\left(\mathrm{mg} \mathrm{L}^{-1}\right)$ & - & - & - \\
TDN $\left(\mathrm{mg} \mathrm{L}^{-1}\right)$ & $\mathrm{X}$ & - & $\mathrm{X}$ \\
Log of $\mathrm{Q}\left(\mathrm{m}^{3} \mathrm{~s}^{-1}\right)$ & $\mathrm{X}$ & - & $\mathrm{X}$ \\
Location $($ tributary vs. main stem) & - & - & - \\
DOC $: \mathrm{TDN}$ molar ratio & $\mathrm{X}$ & $\mathrm{X}$ & - \\
TDN x log of drainage area interaction & $\mathrm{X}$ & - & $\mathrm{X}$ \\
DOC x log of drainage area interaction & - & - & - \\
\hline Model AIC & 336.85 & 542.14 & 263.59 \\
Overall model $r^{2}$ & 0.789 & 0.153 & 0.795 \\
Overall model $p$ value & $<0.008$ & 0.0082 & $<0.008$ \\
\hline
\end{tabular}

(Fig. 4c) suggest that organic carbon availability modulates inorganic nitrogen loading to streams. DOC availability has been shown to control $\mathrm{NO}_{3}^{-}$concentrations across terrestrial and aquatic ecosystems through a variety of coupled microbial processes (Hedin et al., 1998; Kaushal and Lewis, 2005; Taylor and Townsend, 2010). Additionally, the average DOC: $\mathrm{NO}_{3}^{-}$ratio (i.e., the slope of this relationship) varied significantly across categories. Variation in this relationship is likely driven by a combination of differential $\mathrm{N}$ loading across categories as well as different capacities for microbial $\mathrm{N}$ uptake and removal.
We speculate that the location of infrastructure on the landscape may affect the relative importance of direct anthropogenic loading vs. microbial processes on $\mathrm{DOC}: \mathrm{NO}_{3}^{-}$ratios of stream water. For instance we found high concentrations of $\mathrm{NO}_{3}^{-}$and low DOC in streams draining septic systems. Much of this excess $\mathrm{NO}_{3}^{-}$is likely from septic plumes, but the lack of DOC may be the result of microbial $\mathrm{C}$ mineralization along subsurface flow paths. On the other end of the spectrum, there were very low $\mathrm{NO}_{3}^{-}$and TDN concentrations in streams draining watersheds in the floodplain preservation category, which were also newly developed. In this 
case, the higher $\mathrm{C}: \mathrm{N}$ may have been driven by lower $\mathrm{N}$ leakage rates as well as improved ecological function of the preserved floodplain wetlands to remove any $\mathrm{N}$ that does enter the groundwater from stormwater or sewage leaks.

Understanding the spatial variability in $\mathrm{N}_{2} \mathrm{O}$ concentrations, as well as the processes responsible for $\mathrm{N}_{2} \mathrm{O}$ production and $\mathrm{NO}_{3}^{-}$removal in watersheds, is useful for informing watershed management. The relationship between $\mathrm{N}_{2} \mathrm{O}$ and $\mathrm{CO}_{2}$ can provide insight into production mechanisms because nitrification consumes $\mathrm{CO}_{2}$ while denitrification simultaneously produces $\mathrm{N}_{2} \mathrm{O}$ and $\mathrm{CO}_{2}$. We found a strong positive relationship between $\mathrm{N}_{2} \mathrm{O}$ saturation and $\mathrm{CO}_{2}$ concentrations, suggesting that denitrification was the primary source of $\mathrm{N}_{2} \mathrm{O}$ (Fig. 5c). By contrast, very low DOC: $\mathrm{NO}_{3}^{-}$ ratios (Fig. 2) in stream water with the highest $\mathrm{N}_{2} \mathrm{O}$ saturation (Fig. 3a) suggest that nitrification was the dominant process at these sites. Taylor and Townsend (2010) suggest that the ideal DOC: $\mathrm{NO}_{3}^{-}$stoichiometry for denitrification is $1: 1$ and that persistent conditions below that are more ideal for nitrification. $\mathrm{DOC}: \mathrm{NO}_{3}^{-}$was consistently below 1 in streams in septic system infrastructure, suggesting that in-stream denitrification would be carbon limited. We measured DOC: $\mathrm{NO}_{3}^{-}$consistently above 1 at sites in riparian/floodplain preservation typology, suggesting $\mathrm{NO}_{3}^{-}$was limiting for in-stream denitrification in this infrastructure category. Conversely, the mean stoichiometric ratio was consistently near 1 in sites with inline SWM wetlands and stream burial, suggesting that denitrification may be occurring within the stream channel at these sites. While DOC: $\mathrm{NO}_{3}^{-}$stoichiometry in watersheds with septic systems appeared more favorable for nitrification, the positive $x s \mathrm{CO}_{2}$-AOU vs. $\mathrm{N}_{2} \mathrm{O}$ relationships in these streams suggest that these gases were produced anaerobically (by denitrification). One possible explanation for this discrepancy is that the $\mathrm{N}_{2} \mathrm{O}$ and $\mathrm{CO}_{2}$ observed in the stream were produced under stoichiometric conditions more favorable for denitrification along groundwater flow paths prior to emerging in the stream channel. Denitrification occurring along groundwater flow paths may draw down the DOC concentration as it is converted to $\mathrm{CO}_{2}$; however, the initial $\mathrm{N}$ load in septic plumes may be too high to noticeably decline. Pabich et al. (2001) documented this phenomenon, in which DOC concentrations in a septic plume were quite high $\left(>20 \mathrm{mg} \mathrm{L}^{-1}\right)$ in the upper part of the plume and declined exponentially, resulting in a very low DOC: $\mathrm{NO}_{3}^{-}$ratio at depth.

Overall, the relationships between $\mathrm{CH}_{4}$ and $\mathrm{CO}_{2}$ were much weaker and more variable than the relationships between $\mathrm{CO}_{2}$ and $\mathrm{N}_{2} \mathrm{O}$ (Fig. 4). While $\mathrm{CO}_{2}$ and $\mathrm{CH}_{4}$ are sometimes correlated in wetlands and rivers with low oxygen (Richey et al., 1998), this was not the case for our study sites. Instead, $\mathrm{CO}_{2}$ and $\mathrm{N}_{2} \mathrm{O}$ were highly coupled, suggesting prevalence of $\mathrm{NO}_{3}^{-}$as a terminal electron acceptor over $\mathrm{CO}_{2}$.

\subsection{Effects of infrastructure on $\mathrm{N}_{2} \mathrm{O}$ saturation and emissions}

The present study documents some of the highest $\mathrm{N}_{2} \mathrm{O}$ concentrations currently reported in the literature for streams and rivers, ranging from 0.009 to $0.55 \mu \mathrm{M}$, with a median value of $0.07 \mu \mathrm{M}$ and mean of $0.11 \mu \mathrm{M} \mathrm{N} \mathrm{N}_{2} \mathrm{O}-\mathrm{N}$. This range of concentration is greater than that reported for headwater agricultural and mixed land use streams in the Midwestern United States $(0.03-0.07 \mu \mathrm{M}$, Werner et al., $2012 ; 0.03$ to $0.15 \mu \mathrm{M}$, Beaulieu et al., 2008). A similar range of dissolved $\mathrm{N}_{2} \mathrm{O}$ concentrations was reported for macrophyte-rich agriculturally influenced streams in New Zealand $(0.06$ to $0.60 \mu \mathrm{M}$, Wilcock and Sorrell, 2008). The only report of higher dissolved $\mathrm{N}_{2} \mathrm{O}$ concentrations in streams is from a subtropical stream receiving irrigation runoff, livestock waste, and urban sewage (saturation ratio maximum of 60 compared with 47 in this study; Harrison et al., 2005).

Average daily $\mathrm{N}_{2} \mathrm{O}$ emissions were high, ranging from 5.1 to $149.6 \mathrm{mg} \mathrm{N}_{2} \mathrm{O}-\mathrm{N} \mathrm{m}^{2} \mathrm{~d}^{-1}$. Our value rates fall on the high end compared with numerous studies of $\mathrm{N}_{2} \mathrm{O}$ emission from urban and agriculturally influenced waterways, including agricultural drains in Japan (maximum $=179 \mathrm{mg} \mathrm{N} \mathrm{m}^{2} \mathrm{~d}^{-1}$; Hasegawa et al., 2000) or the Humber Estuary, UK (maximum $=121 \mathrm{mg} \mathrm{N} \mathrm{m}^{2} \mathrm{~d}^{-1}$; Barnes and Owens, 1998). When the highest site (DRKV) is removed, these average daily fluxes remain high (range from 5.1 to $12.3 \mathrm{mg} \mathrm{N} \mathrm{m}^{2} \mathrm{~d}^{-1}$ ) compared with estimates reported for nitrogen-enriched agricultural and mixed land use streams in the Midwestern U.S. from Beaulieu et al. (2008) (mean $=0.84$ and maximum $=6.4 \mathrm{mg} \mathrm{N}_{2} \mathrm{O}$ $\mathrm{N} \mathrm{m}^{2} \mathrm{~d}^{-1}$ ). Laursen and Seitzinger (2004) reported higher maximum rates $\left(20 \mathrm{mg} \mathrm{N} \mathrm{m}^{2} \mathrm{~d}^{-1}\right)$ to our overall median $\mathrm{N}_{2} \mathrm{O}$ emission rates $\left(13.8 \mathrm{mg} \mathrm{N} \mathrm{m}^{2} \mathrm{~d}^{-1}\right)$ and the maximum daily rates measured in tropical agricultural streams in Mexico $\left(\right.$ mean $=1.2$ maximum $=58.8 \mathrm{mg} \mathrm{N}_{2} \mathrm{O}-\mathrm{N} \mathrm{m}^{2} \mathrm{~d}^{-1}$; Harrison and Matson, 2003). While our measured $\mathrm{N}_{2} \mathrm{O}$ saturation ratios were highly correlated solute concentrations and redox conditions (Table 4 ), emission rates were sensitive to the gas transfer velocity $\left(k_{600}\right)$, which varied by 2 orders of magnitude in our study (Table 6), and fell within the range of values estimated by Raymond et al. (2012).

Correlations between TDN and $\mathrm{N}_{2} \mathrm{O}$ concentrations in this study highlight the role of urban $\mathrm{N}$ loading on GHG production along urban flow paths, which include groundwater, within pipes, and along the stream networks (Tables 3 and 4). While urban streams receive a mixture of different $\mathrm{N}$ sources including fertilizer, wastewater, and atmospheric deposition (e.g., Kaushal et al., 2011; Pennino et al., 2016), the location of aging gravity sewers adjacent to stream channels is likely to influence the relative importance of sewage on $\mathrm{N}$ and $\mathrm{N}_{2} \mathrm{O}$ loading to streamwater. While this source of $\mathrm{N}_{2} \mathrm{O}$ emission is likely a small portion of the global budget, gaseous losses of $\mathrm{N}$ can contribute a significant portion of watershed-scale $\mathrm{N}$ budgets, which are relevant to nutrient management (Gard- 
ner et al., 2016). $\mathrm{N}_{2} \mathrm{O}$ emissions from uncollected human waste (i.e., leaky sanitary sewer lines, septic system effluent, dug pits) are largely unmeasured globally (Strokal and Kroeze, 2014; UNEP, 2013) and warrant further study in the context of watershed management as well as local GHG accounting. Direct emissions from wastewater treatment plants are well documented (Foley et al., 2010; Townsend-Small et al., 2011; Strokal and Kroeze, 2014; UNEP, 2013); however, the upstream losses of $\mathrm{N}_{2} \mathrm{O}$ from delivery pipes into streams and rivers are not well documented (Short et al., 2014). Short et al. (2014) measured $\mathrm{N}_{2} \mathrm{O}$ concentrations in WWTP influent in Australia and determined that sanitary sewers are consistently supersaturated with $\mathrm{N}_{2} \mathrm{O}$, with concentrations in excess of equilibrium by as much as $3.5 \mu \mathrm{M}$. Average daily sewer pipe $x s \mathrm{~N}_{2} \mathrm{O}$ concentrations were $0.55 \mu \mathrm{M}$, which is nearly identical to the maximum $x s \mathrm{~N}_{2} \mathrm{O}$ measured in the present study $(0.54 \mu \mathrm{M})$. While wastewater only contributes a portion of excess $\mathrm{N}$ in urban streams, further accounting for this source is necessary to improve municipal $\mathrm{N}_{2} \mathrm{O}$ budgets.

Synoptic surveys of $\mathrm{N}_{2} \mathrm{O}$ saturation in Red Run and Dead Run in this study provide evidence that the entire network is a net source of $\mathrm{N}_{2} \mathrm{O}$ (Fig. 5). $\mathrm{N}_{2} \mathrm{O}$ saturation shows a significant decline with increasing drainage area (Table 6, Fig. 5), suggesting that emissions outpace new sources to the water column. Variability in gas concentration headwater sites and along the third-order stream networks is largely explained by a combination of discharge and/or drainage area as well as $\mathrm{N}$ concentrations and $\mathrm{C}: \mathrm{N}$ stoichiometry in streamwater.

\subsection{Effects of infrastructure on $\mathrm{CH}_{4}$ saturation and emissions}

Methane was consistently supersaturated across all streams in this study and varied significantly across headwater infrastructure categories. The highest $\mathrm{CH}_{4}$ saturation ratios were measured in sites with riparian reconnection (RRRM and RRRB) followed by streams draining inline SWM wetlands (DRKV and DRGG; Fig. 3 as with $\mathrm{CO}_{2}$ ). $\mathrm{CH}_{4}$ saturation was negatively correlated with $\mathrm{DO}$; however, $\mathrm{CH}_{4}$ was positively correlated with DOC : $\mathrm{NO}_{3}^{-} \cdot \mathrm{CO}_{2}$ and $\mathrm{N}_{2} \mathrm{O}$, by contrast, were more strongly and positively correlated with TDN (Table 4). These patterns suggest that, along with redox conditions, carbon availability may modulate $\mathrm{CH}_{4}$ production as well.

$\mathrm{CH}_{4}$ concentrations in our study ranged from 0.06 to $6.08 \mu \mathrm{mol} \mathrm{L}{ }^{-1}$, which is equivalent to the mean \pm standard deviation of concentrations reported by a meta-analysis by Stanley et al. (2016). The saturation ratio (3.0 to 2157) fell within the lower range of previously measured values in agricultural streams in Canada (saturation ratio of 500 to 5000; Baulch et al., 2011a). Mean daily $\mathrm{CH}_{4}$ emissions estimates in this study ranged from 2.6 to $103.5 \mathrm{mg} \mathrm{CH}_{4}$ $\mathrm{C} \mathrm{m}^{2} \mathrm{~d}^{-1}$ and are comparable to measurements in agricultural streams of New Zealand (Wilcock and Sorrel, 2008; 17-56 $\mathrm{mg} \mathrm{CH}_{4}-\mathrm{C} \mathrm{m}^{2} \mathrm{~d}^{-1}$ ) and southern Canada (20$172 \mathrm{mg} \mathrm{C} \mathrm{m}^{2} \mathrm{~d}^{-1}$, Baulch et al., 2011); however, these stud- ies also measured ebullitive (i.e., bubble) fluxes, whereas the present study only examined diffusive emissions. Stanley et al. (2016) reported the average of all current $\mathrm{CH}_{4}$ emission rates to be $98.7 \mathrm{mg} \mathrm{CH}_{4}-\mathrm{C} \mathrm{m}^{2} \mathrm{~d}^{-1}$, with a minimum of -125.3 and a maximum of 5194 overall. While the $\mathrm{CH}_{4}$ emission estimates in the present study have a large margin of uncertainty due to the nature of estimating gas flux parameters as well as the lack of ebullitive flux measurements, our sites were consistently sources to the atmosphere throughout the year at both headwater sites (Fig. 3) and throughout third-order drainage networks (Fig. 5b). Differences in $\mathrm{CH}_{4}$ abundance across infrastructure categories, as well as the negative relationship between $\mathrm{CH}_{4}$ saturation and TDN, suggest that $\mathrm{CH}_{4}$ may increase if TDN declines with the addition of stormwater wetlands and floodplain reconnection in urban areas.

\section{Conclusions}

Urban watersheds are highly altered systems, with heterogeneous forms of infrastructure and water quality impairment. The present study demonstrates that $\mathrm{N}_{2} \mathrm{O}$ and $\mathrm{CH}_{4}$ saturation and emissions from urbanized headwaters are on the high end of estimates currently reported in the literature. Variations in urban infrastructure (i.e., SWM wetlands, riparian connectivity, septic systems) influenced the $\mathrm{C}: \mathrm{N}$ stoichiometry and redox state of urban streams. These in-stream variables, along with potential direct sources from leaky sanitary sewer lines, may contribute to increased GHG production and/or delivery to streams. Our results suggest that $\mathrm{N}$ from septic plumes and sanitary sewer lines is the principal source of $\mathrm{N}_{2} \mathrm{O}$ saturation in our study sites. Dissolved inorganic $\mathrm{N}$ is highly correlated with $\mathrm{N}_{2} \mathrm{O}$ in our study sites, and the highest values are only present in watersheds with aging sanitary sewer infrastructure or septic systems. Our observations of $\mathrm{N}_{2} \mathrm{O}$ saturation and emissions from urban and suburban headwater streams are comparable with streams and ditches in intensive agricultural watersheds (Harrison and Matson, 2003; Outram and Hiscock, 2012). These results suggest that streams draining medium-to-low-density suburban or exurban land cover are comparable to those in intensively managed agricultural areas in terms of $\mathrm{N}_{2} \mathrm{O}$ emissions.

Code availability. The authors are happy to share any and all codes used to produce this paper. Please contact the corresponding author with inquiries about the codes used.

Data availability. The authors have provided tables of all raw data collected for this study in the Supplement files. These datasets will additionally be available as part of the Baltimore Ecosystem Study LTER site archive (www.beslter.org). 


\section{The Supplement related to this article is available online at https://doi.org/10.5194/bg-14-2831-2017-supplement.}

Author contributions. R. Smith, S. Kaushal, C. Welty, and M. Pennino selected sampling sites based on infrastructure typology. R. Smith, S. Kaushal, and J. Beaulieu designed the gas and solute sampling design. R. Smith and J. Beaulieu analyzed samples for solute and gas concentrations respectively. C. Welty collected continuous flow data from headwater gaging stations. J. Beaulieu provided key insights into the interpretation of gas concentrations and statistical analyses and gas flux estimations. M. Pennino provided data used for estimating $K_{20}$. S. Kaushal and C. Welty provided funding for the project. All coauthors provided feedback on multiple versions of the manuscript.

Competing interests. The authors declare that they have no conflict of interest.

Acknowledgements. The authors gratefully acknowledge funding from the National Science Foundation Water Sustainability and Climate program (NSF grants CBET-1058038 and CBET1058502) as well as the scientific infrastructure provided by the Baltimore Ecosystem Study LTER (www.beslter.org; NSF grant DEB-1027188). Field data collection was also partially supported by NOAA grant NA10OAR431220 to the Center for Urban Environmental Research and Education (http://cuere.umbc.edu) and the Water Resources mission area of the US Geological Survey (http://water.usgs.gov). Daniel Jones provided advice on spatial analyses, and numerous individuals including Tamara Newcomer, Tom Doody, Evan McMullen, John Urban, Shahan Haq, Julia Gorman, Julia Miller, John Kemper, Erin Stapleton, and Joshua Cole provided field assistance and/or feedback on drafts of this manuscript. The views expressed in this article are those of the authors and do not necessarily reflect the views or policies of the US Environmental Protection Agency.

Edited by: T. J. Battin

Reviewed by: two anonymous referees

\section{References}

Aitkenhead-Peterson, J. A. and McDowell, W. H.: Soil C:N ratio as a predictor of annual riverine DOC flux at local and global scales, Global Biogeochem. Cy., 14, 127, https://doi.org/10.1029/1999GB900083, 2000.

Alshboul, Z., Encinas-Fernandez, J., Hofmann, H., and Lorke, A.: Export of dissolved methane and carbon dioxide with effluents from municipal wastewater treatment plants, Envir. Sci. Tech. Lib., 50, 5555-5563, 2016.

Baltimore County Department of Planning: Master Plan 2010, available at: http://resources.baltimorecountymd.gov/ Documents/Planning/masterplan/masterplan2010.pdf (last access: 29 December 2015), 2010.
Baltimore County Government: GIS Data Download, available at: http://www.baltimorecountymd.gov/Agencies/infotech/GIS/ datadownload.html (last access: 9 May 2017), 2002.

Barnes, J. and Owens, N. J. P.: Denitrification and nitrous oxide concentrations in the Humber Estuary, UK, and adjacent coastal zones, Mar. Pollut. Bull., 37, 247-260, 1998.

Battin, T. J., Kaplan, L. A., Findlay, S. E. G., Hopkinson, C., Marti, E., Packman, A. I., Newbold, J. D., and Sabater, F.: Biophysical controls on organic carbon fluxes in fluvial networks, Nat. Geosci., 1, 95-100, https://doi.org/10.1038/ngeo101, 2008.

Baulch, H. M., Dillon, P. J., Maranger, R., and Schiff, S. L.: Diffusive and ebullitive transport of methane and nitrous oxide from streams: Are bubble-mediated fluxes important? J. Geophys. Res., 116, 1-15, https://doi.org/10.1029/2011JG001656, 2011.

Beaulieu, J. J., Arango, C. P., Hamilton, S. K., and Tank, J. L.: The production and emission of nitrous oxide from headwater streams in the Midwestern United States, Glob. Change Biol., 14, 878-894, https://doi.org/10.1111/j.1365-2486.2007.01485.x, 2008.

Beaulieu, J. J., Arango, C. P., and Tank, J. L.: The effects of season and agriculture on nitrous oxide production in headwater streams, J. Environ. Qual., 38, 637-646, https://doi.org/10.2134/jeq2008.0003, 2009.

Beaulieu, J. J., Shuster, W. D., and Rebholz, J. A.: Nitrous oxide emissions from a large, impounded river: the Ohio River, Environ. Sci. Technol., 44, 7527-7533, 2010.

Beaulieu, J. J., Tank, J. L., Hamilton, S. K, Wollheim, W. M., Hall Jr., R. O., Mulholland, P. J., Peterson, B. J., Ashkenas, L. R., Cooper, L. W., Dahm, C. N., Dodds, W. K., Grimm, N. B., Johnson, S. L., McDowell, W. H., Poole, G. C., Valette, H. M., Arango, C. P., Bernot, M. J., Burgin, A. J., Crenshaw, C. L., Helton, A. M., Johnson, L. T., O’Brien, J. M., Potter, J. D., Sheibley, R. W., Sobota, D. J., and Thomas, S. M.: Nitrous oxide emission from denitrification in stream and river networks, P. Natl. Acad. Sci., 108, 214-219, https://doi.org/10.1073/pnas.1011464108, 2011.

Beaulieu, J. J., Mayer, P. M., Kaushal, S. S., Pennino, M. J., Arango, C. P., Balz, D. A., Canfield, T. J., Elonen, C. M., Fritz, K. M., Hill, B. H., Ryu, H., and Santo Domingo, J.W.: Effects of urban stream burial on organic matter dynamics and reach scale nitrate retention, Biogeochemistry, 121, 107-126, https://doi.org/10.1007/s10533-014-9971-4, 2014.

Beaulieu, J. J., Golden, H. E., Knightes, C. D., Mayer, P. M., Kaushal, S. S., Pennino, M. J., Arango, C. P., Balz, D. A., Elonen, C. M., Fritz, K. M., and Hill, B.: Urban Stream Burial Increases Watershed-Scale Nitrate Export, Plos One, 10, e0132256, https://doi.org/10.1371/journal.pone.0132256, 2015.

Bernot, M. J., Sobota, D. J., Hall, R. O., Mulholland, P. J., Dodds, W. K., Webster, J. R., Tank, J. L., Ashkenas, L. R., Cooper, L. W., Dahm, C. N., Gregory, S. V., Grimm, N. B., Hamilton, S. K., Johnson, S. L., McDowell, W. H., Meyer, J. L., Peterson, B. J., Poole, G. C., Valett, H. M., Arango, C. P., Beaulieu, J. J., Burgin, A. J., Crenshaw, C., Helton, A. M., Johnson, L., Merriam, J., Niederlehner, B. R., O’Brien, J. M., Potter, J. D., Sheibley, R. W., Thomas, S. M., and Wilson, K.: Inter-regional comparison of land-use effects on stream metabolism, Freshwater Biol., 55, 1874-1890, 2010. 
Bettez, N. D. and Groffman, P. M.: Denitrification potential in stormwater control structures and natural riparian zones in an urban landscape, Envir. Sci. Tech. Lib., 46, 10909-10917, 2012.

Bridgham, S. D., Cadillo-Quiroz, H., Keller, J. K., and Zhuang, Q.: Methane emissions from wetlands: biogeochemical, microbial, and modeling perspectives from local to global scales, Glob. Change Biol., 19, 1325-1346, 2013.

Caraco, N. F., Lampman, G., Cole, J. J., Limburg, K. E., Pace, M. L., and Fischer, D.: Microbial assimilation of DIN in a nitrogen rich estuary: Implications for food quality and isotope studies, Mar. Ecol.-Prog. Ser., 167, 59-71, https://doi.org/10.3354/meps167059, 1998.

Ciais, P., Sabine, C., Bala, G., Bopp, L., Brovkin, V., Canadell, J., Chhabra, A., DeFries, R., Galloway, J., Heimann, M., Jones, C., Le Quéré, C., Myneni, R. B., Piao, S., and Thornton, P.: Carbon and Other Biogeochemical Cycles, in: Climate Change 2013: The Physical Science Basis. Contribution of Working Group I to the Fifth Assessment Report of the Intergovernmental Panel on Climate Change, edited by: Stocker, T. F., Qin, D., Plattner, G.K., Tignor, M., Allen, S. K., Boschung, J., Nauels, A., Xia, Y., Bex, V., and Midgley, P. M., Cambridge University Press, Cambridge, United Kingdom and New York, NY, USA, 2013.

Cole, J. J., Prairie, Y. T., Caraco, N. F., McDowell, W. H., Tranvik, L. J., Striegl, R. G., Duarte, C. M., Kortelainen, P., Downing, J. A., Middelburg, J. J., and Melack, J. M.: Plumbing the Global Carbon Cycle: Integrating Inland Waters into the Terrestrial Carbon Budget, Ecosystems, 10, 172-185, https://doi.org/10.1007/s10021-006-9013-8, 2007.

Collins, K. A., Lawrence, T. J., Stander, E. K., Jontos, R. J., Kaushal, S. S., Newcomer, T. A., Grimm, N. B., and Cole Ekberg, M. L.: Opportunities and challenges for managing nitrogen in urban stormwater: A review and synthesis, Ecol. Eng., 36, 1507-1519, https://doi.org/10.1016/j.ecoleng.2010.03.015, 2010.

Daniel, M. H. B., Montebelo, A. A., Bernardes, M. C., Ometto, J. P. H. B., de Camargo, P. B., Krusche, A. V., Ballester, M. V., Victoria, R. L., and Martinelli, L. A.: Effects of urban sewage on dissolved oxygen, dissolved inorganic and organic carbon, and electrical conductivity of small streams along a gradient of urbanization in the Piracicaba River basin, Water Air Soil Poll., 136, 189-206, 2001.

Dodds, W. K., Marti, E., Tank, J. L., Pontius, J., Grimm, N. B., Hamilton, S. K., Bowden, W. B., McDowell, W. H., Peterson, B. J., Valett, H. M., Webster, J. R., and Gregory, S.: Carbon and nitrogen stoichiometry and nitrogen cycling rate in streams, Oecologia, 140, 458-467, 2004.

Dinsmore, K. J., Billett, M. F., and Moore, T. R.: Transfer of carbon dioxide and methane through soil-water-atmosphere system at Mer Bleue peatland, Canada, Hydrol. Process., 23, 330-341, https://doi.org/10.1002/hyp.7158, 2009.

Divers, M. T., Elliott, E. M., and Bain, D. J.: Constraining nitrogen inputs to urban streams from leaking sewer infrastructure using inverse modeling: Implications for DIN retention in urban environments, Environ. Sci. Technol., 47, 1816-1823, 2013.

Doyle, M. W., Stanley, E. H., Havlick, D. G., Kaiser, M. J., Steinbach, G., Graf, W. L., Galloway, G. E., and Riggsbee, J. A.: Aging Infrastructure and Ecosystem Restoration, Science, 319, 286-287, 2008.
Dubnick, A., Barker, J., Sharp, M. J., Wadham, J. L., Lis, G., Telling, J., Fitzsimons, S., and Jackson, M.: Characterization of dissolved organic matter (DOM) from glacial environments using total fluorescence spectroscopy and parallel factor analysis, Ann. Glaciol., 51, 111-122, https://doi.org/10.3189/172756411795931912, 2010.

Dlugokencky, E.: NOAA/ESRL, available at: www.esrl.noaa.gov/ gmd/ccgg/trends_ch4/), last access: 19 May 2017.

Findlay, S. E. G., McDowell, W. H., Fischer, D., Pace, M. L., Caraco, N., Kaushal, S. S., and Weathers, K. C.: Total carbon analysis may overestimate organic carbon content of fresh waters in the presence of high dissolved inorganic carbon, Limnol. Oceanogr.-Meth., 8, 196-201, 2010.

Foley, J. A., Defries, R., Asner, G. P., Barford, C., Bonan, G., Carpenter, S. R., Chapin, F. S., Coe, M. T., Daily, G. C., Gibbs, H. K., Helkowski, J. H., Holloway, T., Howard, E. A., Kucharki, C. J., Monfreda, C., Patz, J. A., Prentice, I. C., Ramankutty, N., and Snyder, P. K.: Global consequences of land use, Science, 309, 570-574, https://doi.org/10.1126/science.1111772, 2005.

Foley, J., de Haas, D., Yuan, Z., and Lant, P.: Nitrous oxide generation in full-scale biological nutrient removal wastewater treatment plants, Water Res., 44, 831-844, https://doi.org/10.1016/j.watres.2009.10.033, 2010.

Gabor, R. S., Eilers, K., McKnight, D. M., and Fierer, N., and Anderson, S. P.: From the litter layer to the saprolite: Chemical changes in water-soluble soil organic matter and their correlation to microbial community composition, Soil Biol. Biochem., 68, 166-176, https://doi.org/10.1016/j.soilbio.2013.09.029, 2014.

Gallo, E. L., Lohse, K. A., Ferlin, C. M., Meixner, T., and Brooks, P. D.: Physical and biological controls on trace gas fluxes in semiarid urban ephemeral waterways, Biogeochemistry, 121, 189207, https://doi.org/10.1007/s10533-013-9927-0, 2014.

Gardner, J. R., Fisher, T. R., Jordan, T. E., and Knee, K. L.: Balancing watershed nitrogen budgets: accounting for biogenic gases in streams, Biogeochemistry, 127, 231-253 https://doi.org/10.1007/s10533-015-0177-1, 2016.

Google Earth (Version 5.1.3533.1731), Software, Mountain View, CA, Google Inc., available at: https://www.google.com/earth/ (last access: 19 May 2017), 2009.

Harrison, J. and Matson, P. A.: Patterns and controls of nitrous oxide emissions from waters draining a subtropical agricultural valley, Global Biogeochem. Cy., 17, 1080, https://doi.org/10.1029/2002GB001991, 2003.

Harrison, J. A., Matson, P. A., and Fendorf, S. E.: Effects of a diel oxygen cycle on nitrogen transformations and greenhouse gas emissions in a eutrophied subtropical stream, Aquat. Sci., 67, 308-315, https://doi.org/10.1007/s00027-005-0776-3, 2005.

Hasegawa, K., Hanaki, K., Matsu, T., and Hidaka, S.: Nitrous oxide from the agricultural water system contaminated with nigh nitrogen, Chemosphere - Global Change Science, 2, 335-345, 2000.

Hedin, L. O., Von Fischer, J. C., Ostrom, N. E., Kennedy, B. P., Brown, M. G., and Robertson, P. G.: Thermodynamic Constraints on Nitrogen Transformations and other Biogeochemical Processes at Soil-Stream Interfaces, Ecological Society of America, 79, 684-703, 1998.

Helton, A. M., Ardón, M., and Bernhardt, E. S.: Thermodynamic constraints on the utility of ecological stoichiometry for explain- 
ing global biogeochemical patterns, Ecol. Lett., 18, 1049-1056, https://doi.org/10.1111/ele.12487, 2015.

Huguet, A., Vacher, L., Relexans, S., Saubusse, S., Froidefond, J. M., and Parlanti, E.: Properties of fluorescent dissolved organic matter in the Gironde Estuary, Org. Geochem., 40, 706-719, https://doi.org/10.1016/j.orggeochem.2009.03.002, 2009.

Kaushal, S. S. and Belt, K. T.: The urban watershed continuum: evolving spatial and temporal dimensions, Urban Ecosystems, 15, 409-435, https://doi.org/10.1007/s11252-012-0226-7, 2012.

Kaushal, S. S. and Lewis, W. M.: Fate and transport of organic nitrogen in minimally disturbed montane streams of Colorado, USA, Biogeochemistry, 74, 303-321, https://doi.org/10.1007/s10533004-4723-5, 2005.

Kaushal, S. S., Groffman, P. M., Band, L. E., Elliott, E. M., Shields, C. A., and Kendall, C.: Tracking nonpoint source nitrogen pollution in human-impacted watersheds, Environ. Sci. Technol., 45, 8225-8232, 2011.

Kaushal, S. S., McDowell, W. H., and Wollheim, W. M.: Tracking evolution of urban biogeochemical cycles: past, present and future, Biogeochemistry, 121, 1-21, https://doi.org/10.1007/s10533-014-0014-y, 2014a.

Kaushal, S. S., Mayer, P. M., Vidon, P. G., Smith, R. M., Pennino, M. J., Newcomer, T. A., Duan, S., Welty, C., and Belt, K. T.: Land use and climate variability amplify carbon, nutrient, and contaminant pulses: A review with management implications, J. Am. Water Resour. As., 50, 585-614, https://doi.org/10.1111/jawr.12204, 2014b.

Kaushal, S. S., Delaney-Newcomb, K., Findlay, S. E., Newcomer, T. A., Duan, S., Pennino, M. J., Sivirichi, G. M., Sides-Raley, A. M., Walbridge, M. R., and Belt, K. T.: Longitudinal patterns in carbon and nitrogen fluxes and stream metabolism along an urban watershed continuum, Biogeochemistry, 121, 23-44, https://doi.org/10.1007/s10533-014-9979-9, 2014c.

Kaushal, S., McDowell, W. H., Wollheim, W., Newcomer Johnson, T., Mayer, P. M., Belt, K. T., and Pennino, M. J.: Urban Evolution: The Role of Water, Water, 7, 4063-4087, https://doi.org/10.3390/w7084063, 2015.

Knowles, R.: "Denitrification", Microbiological Reviews, 46, 4370, 1982.

Laursen, A. E. and Seitzinger, S. P.: Diurnal patterns of denitrification, oxygen consumption, and nitrous oxide production in rivers measured at the whole-reach scale, Freshwater Biol., 49, 14481458, 2004.

Lenth, R. V.: Least-Squares Means: The R Package lsmeans, J. Stat. Softw., 69, 1-33, 2016.

Mayer, P. M., Groffman, P. M., Striz, E. A., and Kaushal, S. S.: Nitrogen dynamics at the groundwater-surface water interface of a degraded urban stream, J. Environ. Qual., 39, 810-823, https://doi.org/10.2134/jeq2009.0012, 2010.

Newcomer, T. A., Kaushal, S. S., Mayer, P. M., Shields, A. R., Canuel, E. A., Groffman, P. M., and Gold, A. J.: Influence of natural and novel organic carbon sources on denitrification in forest, degraded urban, and restored streams, Ecol. Monogr., 82, 449466, 2012.

Newcomer Johnson, T. A., Kaushal, S. S., Mayer, P. M., and Grese, M. M.: Effects of stormwater management and stream restoration on watershed nitrogen retention, Biogeochemistry, 121, 81-106, https://doi.org/10.1007/s10533-014-9999-5, 2014.
Nevison, C.: Review of the IPCC methodology for estimating nitrous oxide emissions associated with agricultural leaching and runoff, Chemosphere - Global Change Science, 2, 493-500, https://doi.org/10.1016/S1465-9972(00)00013-1, 2000.

NOAA/ESRL: Monitoring Division, Combined Nitrous Oxide data, available at: https://www.esrl.noaa.gov/gmd/hats/ combined/N2O.html (last access: 19 May 2017), updated 17 January 2017.

Ohno, T.: Fluorescence inner-filtering correction for determining the humification index of dissolved organic matter, Environ. Sci. Technol., 36, 742-746, 2002.

Outram, F. N. and Hiscock, K. M.: Indirect nitrous oxide emissions from surface water bodies in a lowland arable catchment: a significant contribution to agricultural greenhouse gas budgets?, Environ. Sci. Technol., 46, 8156-8163, 2012.

Pabich, W. J., Valiela, I., and Hemond, H. F.: Relationship between DOC concentration and vadose zone thickness and depth below water table in groundwater of Cape Cod, U.S.A, Biogeochemistry, 55, 247-268, https://doi.org/10.1023/A:1011842918260, 2001.

Pennino, M. J., Kaushal, S. S., Beaulieu, J. J., Mayer, P. M., and Arango, C. P.: Effects of urban stream burial on nitrogen uptake and ecosystem metabolism: implications for watershed nitrogen and carbon fluxes, Biogeochemistry, 121, 247269, https://doi.org/10.1007/s10533-014-9958-1, 2014.

Pennino, M. J., Kaushal, S. S., Mayer, P. M., Utz, R. M., and Cooper, C. A.: Stream restoration and sewers impact sources and fluxes of water, carbon, and nutrients in urban watersheds, Hydrol. Earth Syst. Sci., 20, 3419-3439, https://doi.org/10.5194/hess-20-3419-2016, 2016.

Pinheiro, J., Bates, D., DebRoy, S., Sarkar, D., and R Core Team: nlme: Linear and nonlinear mixed effects models, R package version 3.1-131, available at: https://CRAN.R-project.org/package= nlme (last access: 5 January 2017), 2012.

Raymond, P. A., Zappa, C. J., Butman, D., Bott, T. L., Potter, J., Mulholland, P. J., Laursen, A. E., McDowell, W. H., and Newbold, D.: Scaling the gas transfer velocity and hydraulic geometry in streams and small rivers, Limnol. Oceanogr.: Fluids \& Environments, 2, 41-53, https://doi.org/10.1215/215736891597669, 2012.

R Core Team: R: a language and environment for statistical computing, 2014.

Richey, J. E., Devol, A. H., Wofsy, S. C., Victoria, R., and Ribiero, M. N. G.: Biogenic Gases and the Oxidation and Reduction of Carbon in Amazon River and Floodplain Waters, Limnol. Oceanogr., 33, 551-561, 1988.

Scripps Institute for Oceanography: The Keeling Curve, available at: https://scripps.ucsd.edu/programs/keelingcurve/ (last access: 19 May 2017), updated 28 February 2017.

Schlesinger, W. H.: Biogeochemistry: An Analysis of Global Change, 2nd edition, New York, Academic Press, 1997.

Seitzinger, S. P., Kroeze, C., and Styles, R. V.: Global distribution of $\mathrm{N}_{2} \mathrm{O}$ emissions from aquatic systems: Natural emissions and anthropogenic effects, Chemosphere - Global Change Science, 2, 267-279, https://doi.org/10.1016/S14659972(00)00015-5, 2000.

Shields, C. A., Band, L. E., Law, N., Groffman, P. M., Kaushal, S. S., Savvs, K., Fisher, G. T., and Belt, K. T.: Streamflow distribution of non-point source nitrogen export from urban-rural catch- 
ments in the Chesapeake Bay watershed, Water Resour. Res., 44, 1-13, https://doi.org/10.1029/2007WR006360, 2008.

Short, M. D., Daikeler, A., Peters, G. M., Mann, K., Ashbolt, N. J., Stuetz, R. M., and Peirson, W. L.: Municipal gravity sewers: An unrecognized source of nitrous oxide, Sci. Total Environ., 468469, 211-218, https://doi.org/10.1016/j.scitotenv.2013.08.051, 2014.

Singh, S., Dutta, S., and Inamdar, S.: Land application of poultry manure and its influence on spectrofluorometric characteristics of dissolved organic matter, Agriculture, Ecosystems and Environment, 193, 25-36, https://doi.org/10.1016/j.agee.2014.04.019, 2014.

Singh, S., Inamdar, S., and Mitchell, M.: Changes in dissolved organic matter (DOM) amount and composition along nested headwater stream locations during baseflow and stormflow, Hydrol. Process., 29, 1505-1520, https://doi.org/10.1002/hyp.10286, 2015.

Smith, R. M. and Kaushal, S. S.: Carbon cycle of an urban watershed: exports, sources, and metabolism, Biogeochemistry, 126, 173-195, https://doi.org/10.1007/s10533-015-0151-y, 2015.

Søvik, A. K., Augustin, J., Heikkinen, K., Huttunen, J. T., Necki, J. M., Karjalainen, S. M., Kløve, B., Liikanen, A., Mander, Ü., Puustinen, M., Teiter, S., and Wachniew, P.: Emission of the greenhouse gases nitrous oxide and methane from constructed wetlands in Europe, J. Environ. Qual., 35, 2360-2373, https://doi.org/10.2134/jeq2006.0038, 2006.

Stanley, E. H., Casson, N. J., Christel, S. T., Crawford, J. T., Loken, L. C., and Oliver, S. K.: The ecology of methane in streams and rivers: patterns, controls, and global significance, Ecol. Monogr., 82, 146-171, 2016.

Strokal, M. and Kroeze, C.: Nitrous oxide $\left(\mathrm{N}_{2} \mathrm{O}\right)$ emissions from human waste in 1970-2050, Current Opinion in Environmental Sustainability, 9-10, 108-121, https://doi.org/10.1016/j.cosust.2014.09.008, 2014.

Stumm, W. and Morgan, J. J.: Aquatic chemistry: An introduction emphasizing chemical equilibria in natural waters, New York, John Wiley, 1981.

Taylor, P. G. and Townsend, A. R.: Stoichiometric control of organic carbon-nitrate relationships from soils to the sea, Nature, 464, 1178-1181, https://doi.org/10.1038/nature08985, 2010.

Townsend-Small, A., Pataki, D. E., Czimczik, C. I., and Tyler, S. C.: Nitrous oxide emissions and isotopic composition in urban and agricultural systems in southern California, J. Geophys. Res., 116, G01013, https://doi.org/10.1029/2010JG001494, 2011.

Tsivoglou, E. C. and Neal, L. A.: Tracer measurement of rearation: III. Predicting the rearation capacity of inland streams, J. Water Pollut. Con. F., 48, 2669-2689, 1976.

UNEP (United Nations Environment Programme): Drawing Down $\mathrm{N}_{2} \mathrm{O}$ To Protect Climate and the Ozone Layer, 2013.

US Geological Survey: National Water Information System data available on the World Wide Web (USGS Water Data for the Nation), Dead Run Franklintown, available at: http://waterdata. usgs.gov/md/nwis/uv/?site_no=01589330, DR1, available at: http://waterdata.usgs.gov/md/nwis/uv?site_no=01589317, DR2, available at: http://waterdata.usgs.gov/md/nwis/uv?site_no= 01589316, DR3, available at: http://waterdata.usgs.gov/md/ nwis/uv?site_no=01589320, DR4, available at: http://waterdata. usgs.gov/md/nwis/uv?site_no=01589315, DR5, available at: http://waterdata.usgs.gov/md/nwis/uv?site_no=01589312 (last access: 15 January 2015), 2017.

VanderZaag, A. C., Gordon, R. J., Burton, D. L., Jamieson, R. C., and Stratton, G. W.: Greenhouse gas emissions from surface flow and subsurface flow constructed wetlands treating dairy wastewater, J. Environ. Qual., 39, 460-471, https://doi.org/10.2134/jeq2009.0166, 2010.

Weiss, R. F.: The solubility of nitrogen, oxygen and argon in water and seawater, Deep-Sea Res., 17, 721-735. 1970

Weiss, R. F.: Carbon Dioxide in Water and Seawater: The Solubility of a Non-Ideal Gas, Mar. Chem., 2, 203-215, 1974.

Werner, S. F., van Kessel, C., Browne, B. A., and Driscoll, C. T.: Three-dimensional spatial patterns of trace gas concentrations in baseflow-dominated agricultural streams: implications for surface-ground water interactions and biogeochemistry, Biogeochemistry, 107, 319-338, https://doi.org/10.1007/s10533-0109555-x, 2012.

Wilcock, R. J. and Sorrell, B. K.: Emissions of Greenhouse Gases $\mathrm{CH}_{4}$ and $\mathrm{N}_{2} \mathrm{O}$ from Low-gradient Streams in Agriculturally Developed Catchments, Water Air Soil Poll., 188, 155-170, https://doi.org/10.1007/s11270-007-9532-8, 2008.

Wymore, A. S., Rodríguez-Cardona, B., and McDowell, W. H.: Direct response of dissolved organic nitrogen to nitrate availability in headwater streams, Biogeochemistry, 126, 1-10, https://doi.org/10.1007/s10533-015-0153-9, 2015.

Yamamoto, S., Alcauskas, J. B., and Crozier, T. E.: Solubility of methane in distilled water and sea water, J. Chem. Eng. Data, 21, 78-80, https://doi.org/10.1021/je60068a029, 1976.

Yu, Z., Deng, H., Wang, D., Ye, M., Tan, Y., Li, Y., Chen, $\mathrm{Z}$, and $\mathrm{Xu}, \mathrm{S}$.: Nitrous oxide emissions in the Shanghai river network: Implications for the effects of urban sewage and IPCC methodology, Glob. Change Biol., 19, 2999-3010, https://doi.org/10.1111/gcb.12290, 2013.

Zsolnay, A., Baigar, E., Jimenez, M., Steinweg, B., and Saccomandi, F.: Differentiating with fluorescence spectroscopy the sources of dissolved organic matter in soils subjected to drying, Chemosphere, 38, 45-50, 1999.

Zuur, A., Ieno, E. N., Walker, N., Savilev, A. A., and Smith, G. M.: Mixed Effects Models and Extensions in Ecology with R, Spring Science+Business Media, New York, https://doi.org/10.1007/978-0-387-87458-6, 2009.

Zuur, A., Ieno, E. N., and Elphick, C. S.: A protocol for data exploration to avoid common statistical problems, A protocol for data exploration to avoid common statistical problems, Methods in Ecology and Evolution, 1, 3-14, 2010. 